JKAU: Earth Sci., Vol. 20, No. 2, pp: 127-159 (2009 A.D. / 1430 A.H.)

\title{
Occurrence and Geochemical Significance of Carbazoles and Xanthones in Crude Oil from the Western Desert, Egypt
}

\author{
Mohamed M.Y. Bakr \\ Petroleum Geology \& Sedimentology Department, Faculty of Earth \\ Sciences, King Abdulaziz University, Jeddah, Saudi Arabia
}

Received: 29/7/2008

Accepted: 11/10/2008

Abstract. This paper describes an approach that involves the evaluation of the occurrence and distributions of nitrogen- and oxygen-containing aromatic compounds in Egyptian crude oils and source rocks. Carbazoles and xanthones represent nitrogen- and oxygen-containing aromatic compounds, respectively.

Alkylcarbazoles and benzocarbazoles were quantitatively studied in crude oils taken from the Abu Gharadig and Shushan basins in north Western Desert of Egypt in order to investigate their occurrence, concentrations and distributions. The abundances of carbazole, methylcarbazoles and dimethylcarbazoles in the marine Abu Gharadig oils are much higher than that of the terrestrial Shushan oils. The results presented here indicate that thermal maturation can be ruled out as a major factor in controlling the changes in the carbazole ratios in the crude oils. Most likely, source characteristics of the studied samples play a significant role in controlling the distribution of carbazole compounds in reservoired oils. The alkylcarbazoles $1 \mathrm{MC} / 1 \mathrm{MC}+1 \mathrm{EC}, 3 \mathrm{MC} / 4 \mathrm{MC}$ and $18 \mathrm{DMC} / 18 \mathrm{DMC}+1 \mathrm{EC}$ when correlated with specific biomarker signatures provide background information discriminating between two main types of depositional setting: 1) Terrestrial dominated source deposited in oxidizing conditions for the Shushan oils and, 2) marine shale dominated sourced oils deposited in suboxic environments for the Abu Gharadig samples. Similarly, benzocarbazole distributions were found to be independent of maturity, but influenced by organic facies and depositional environments. Therefore, in this study, alkylcarbazole and benzocarbazoles compounds are well suited for the differentiation of Abu Gharadig and Shushan crude oils with respect to origin and variations of facies and depositional environment. 


\begin{abstract}
Using various kinds of Egyptian crude oils derived from marine carbonates, marine clastics and terrestrial sources, the current study indicates that xanthones and its alkylated homologues are abundant only in source extracts and crude oils that have terrestrial organic matter input. This is the second description of xanthones in crude oils, and the first in Egyptian petroleum systems. Overall, based on the data of this study, xanthones signatures show great promise as terrestrial source markers in a given petroleum system.
\end{abstract}

\title{
Introduction
}

Many molecular markers based on aliphatic and aromatic hydrocarbons are proven to be well suited for the characterization of oil families and assignment of source facies, thermal maturity level, degree of preservation, and migration. On the other hand, heterocompounds (nitrogen, oxygen, and sulphur, NSO compounds) that make up a small portion of most crude oils (Tissot and Welte, 1984) have significant implications in petroleum exploration, because their greater structural diversity results in greater variations of their physico-chemical properties. Consequently, heterocompounds can provide useful geochemical clues that trace petroleum molecules back to their biological precursors.

Organic nitrogen compounds occur in crude oils in small amounts, with an average content of $0.1 \%$ by weight (Baxby et al., 1994). Most nitrogen compounds in crude oil are in heterocyclic aromatic structures and are concentrated in the high molecular weight and high boiling point fractions (Ball et al., 1951; Tissot and Welte, 1984; and Baxby et al., 1994). There are two classes of nitrogen compounds; basic (pyridinictype), and non-basic (pyrrolic-type structures), and in most cases, nonbasic predominates over basic nitrogen (Richter et al., 1952; Dorbon et al., 1984; Wilhelms et al., 1992; and Baxby et al., 1994). The pyrrolic nitrogen compounds, particularly the carbazole derivatives, exist in source rocks and crude oils, and have been reported to show great promise as potent geochemical parameters that might play a significant role in exploration and production for crude oil.

The concentrations and the ratio of two benzocarbazole isomers, benzo[a] and benzo[c]carbazole, may be used as an indicator of oil secondary migration distance, with the benzo[a] isomer being removed preferentially (by sorption on to mineral and organic surfaces) during migration (Larter et al., 1996). Such approaches have been confirmed by 
laboratory and field studies (Celgg et al., 1998a-b; Harrison et al., 1997; Li et al., 1997; Wilhelms et al., 1997; Zhu et al., 1997; Horsfield et al., 1998; Li et al., 1999; Larter et al., 2000; Terken and Frewin, 2000).

Based on data from a series of marine carbonate source rocks from a natural maturity sequence [vitrinite reflectance $\left(\mathrm{R}_{\mathrm{o}}\right)$ 0.45-1.30\%] from the Duvernay Formation of the western Canada Basin, Li et al. (1997) noted that the concentrations of carbazoles in the extracts increased with maturation, and a similar trend was observed for benzocarbazoles and the ratio of benzo[a]carbazole/ (benzo[a]carbazole + benzo[c]carbazole) ( $\mathrm{a} / \mathrm{a}+\mathrm{c}$ for simplicity). Horsfield et al. (1998) presented the first report linking carbazole distributions to crude oil maturity, and subsequent discussion has been extended by Clegg et al. (1998a), who provided convincing evidence of source maturity control on alkylcarbazole and benzocarbazole concentrations and distributions in petroleums from the Sonda de Campeche area, Gulf of Mexico.

Despite the common occurrence of organic nitrogen compounds in crude oil, very little work was observed for the influence of source characteristics on the pyrrolic compounds. In a study by Li et al. (1995) several crude oils from marine, freshwater and brackish-brine lacustrine to swampy lake environments revealed no characteristic pyrrolic nitrogen compound distributions that could be assigned to any given depositional conditions. In crude oils of the Rainbow Shekilie-Zamma subbasins of NW Alberta (Canada), the saturated and aromatic hydrocarbon distributions responded to variations in thermal maturity and depositional conditions, whereas pyrrolic nitrogen compounds did not respond to the same extent (Li et al., 1999). Similarly, in the Permian derived Phosphoria oils of Wyoming, molecular parameters based on the saturated hydrocarbons (e.g. $\mathrm{Pr} / \mathrm{Ph}$ and $T s /\left(T_{s}+T m\right)$ ) responded to source organic input, depositional environment and thermal maturity, whereas the pyrrolic nitrogen compounds did not appear to respond to these geological factors (Silliman et al., 2002). On the other hand, there are situations where it is clear that nitrogen compounds respond to changes in depositional environment. For example, Clegg et al. (1997) compared the pyrrolic nitrogen compound distributions in bitumens from two carbonates of the Keg River Formation (Elk Point Group, Middle Devonian, western Canada) representing two different source facies. In crude oils from the Gulf of Suez, a positive correlation between the benzocarbazole [a]/ ([a] $+[\mathrm{c}])$ ratio and $\mathrm{Pr} / \mathrm{Ph}$ and $T s /(T s+T m)$ 
parameters suggested that facies and depositional environment of the relevant source rocks influenced the benzocarbazole distributions in this setting (Bakr and Wilkes, 2002).

The first detailed investigation of oxygen compounds in crude oil was described by Snyder et al. (1968). Xanthones are aromatic oxygencontaining compounds synthesized by fungi, lichens, lower vascular plants, and higher plants (Berti and Bottari, 1968; Culberson, 1969; Chexal et al., 1975; Devon and Scott, 1975; and Peres et al., 2000). Highly substituted xanthones (with hydroxy-, methoxy- and alkylgroups) occur in many different terrestrial plants (Tomasek and Crawford, 1986; and Peres and Nagem, 1997) especially those that prefer tropical or subtropical climates. Many shrubs and herbs, which occur widely in temperate regions of the world, contain xanthones (Wu et al., 1998). Only one recognition of xanthones in crude oil was reported by Oldenburg et al. (2002).

Considering these observations, it appears that our knowledge of the oxygen heterocompounds (xanthones) is only at the very beginning, while the nitrogen heterocompounds (carbazoles and benzocarbazoles) and their behavior in petroleum systems need to be justified for crude oils from various petroleum systems. As far as Egyptian petroleum systems are concerned, and to the best of the author knowledge, carbazoles and benzocarbazoles (nitrogen heterocompounds) have been only reported in the Gulf of Suez crude oils (Bakr and Wilkes, 2002), while xanthones (oxygen heterocompounds) have not yet been reported as constituents of any Egyptian crude oils.

With this background, the present paper deals with the characterization, distributions and consequence geochemical significance of nitrogen (carbazoles and benzocarbazoles) and oxygen (xanthones) heterocompounds in crude oils produced from fields located in the north Western Desert of Egypt. This is the first recognition and description of xanthones compounds in Egyptian crude oils, and is considered as the second reports of these compounds in fossil organic mater. Further, this communication represents the second report describing the occurrence and distributions of carbazoles and benzocarbazoles compounds in Egyptian crude oils. The behavior of nitrogen compounds are then compared with the biomarker parameters in order to ascertain whether nitrogen compounds also inherit compositional variations that could be 
attributed to source rock characteristics. They may therefore be considered ideal for the investigation of how organofacies and depositional environment affect the distribution of heterocompounds in crude oils.

\section{Materials and Methods}

\section{Samples}

Eight crude oil samples from north Western Desert have been utilized in this study. These samples include four oils from Abu Gharadig Basin and four oils from Shushan Basin (Fig. 1 and Table 1). Additionally, other crude oils from the Gulf of Suez and source rock extracts from Khatatba Formation were also analyzed for the characterization of xanthones compounds. Description of these latter samples is not included in this article.

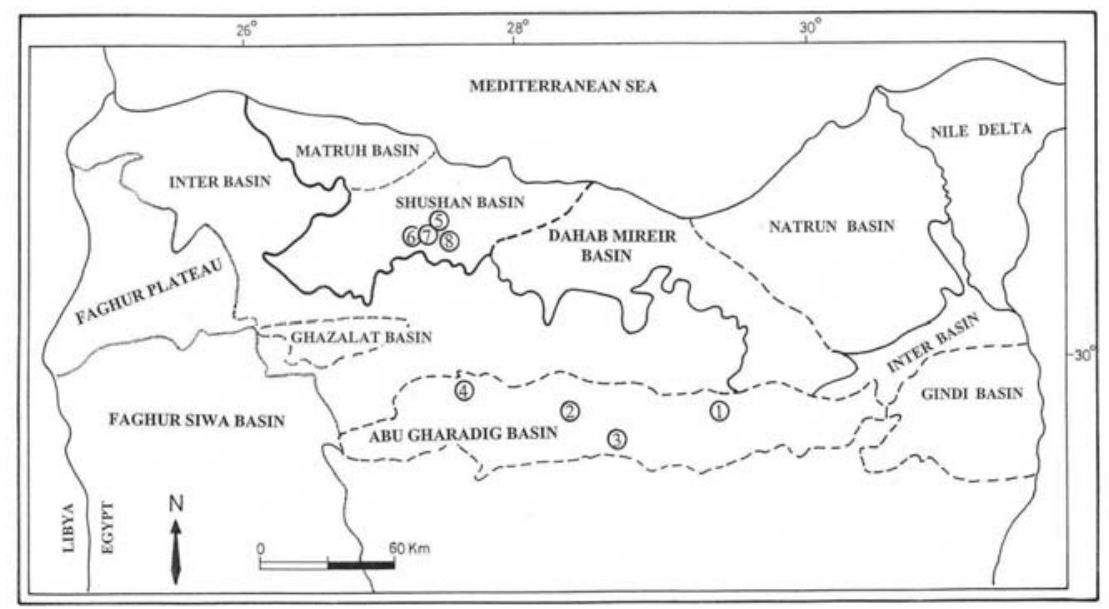

Fig. 1. Map showing the location of the studied oil samples. Numbers of samples refer to Table 1 (after EGPC, 1992 and Petroconsultant, 1997).

\section{Analysis of Pyrrolic Nitrogen and Xanthones Compounds}

Crude oil samples were separated into aliphatic hydrocarbons, aromatic hydrocarbons and NSO compounds by medium pressure liquid chromatography according to the method of Radke et al. (1980). The pyrrolic nitrogen compounds, as well as the xanthones compounds which are constituents of the NSO compound fraction, were then analyzed by gas chromatography-mass spectrometry using a Finnigan MAT 95S mass 
spectrometer coupled with Hewlett Packard 5890B gas chromatograph. The gas chromatograph is equipped with a temperature-programmable injection system (Gerstel KAS 3) and a BPX5 fused silica capillary column (SGE) of $50 \mathrm{~m}$ length, $0.22 \mathrm{~mm}$ i.d. and $0.25 \mu \mathrm{m}$ film thicknesses. Helium was used as the carrier gas. The oven temperature was programmed from 60 to $340^{\circ} \mathrm{C}$ (final hold time $8 \mathrm{~min}$ ) at $3^{\circ} \mathrm{C} / \mathrm{min}$. The mass spectrometer was operated in the electron impact (EI) mode at an electron energy of $70 \mathrm{eV}$ and a source temperature of $260^{\circ} \mathrm{C}$.

Table 1. Selected geochemical ratios in the investigated oil samples.

\begin{tabular}{|c|c|c|c|c|c|c|c|c|c|c|c|}
\hline $\begin{array}{c}\text { Sample } \\
\text { no. }\end{array}$ & Oil well & Wax ${ }^{a}$ & $\begin{array}{l}\mathrm{Pr} / \\
\mathrm{Ph}^{\mathrm{b}}\end{array}$ & $\begin{array}{c}\text { DBT/ } \\
\text { PH }^{c}\end{array}$ & $\begin{array}{l}\mathrm{C}_{35}{ }^{\prime} \\
\mathrm{C}_{34}{ }^{\mathrm{d}}\end{array}$ & $\begin{array}{l}\mathrm{C}_{39} / \\
\mathrm{C}_{27}{ }^{\mathrm{e}} \\
\end{array}$ & $\begin{array}{l}\mathrm{C}_{29} \\
\mathrm{Dia}^{\mathrm{f}}\end{array}$ & $\begin{array}{c}\% \\
20 S^{g}\end{array}$ & $\begin{array}{l}\mathrm{C}_{29} / \\
\mathrm{C}_{30}{ }^{\mathrm{h}}\end{array}$ & $\begin{array}{c}T s / \\
T s+T m)^{\mathrm{i}}\end{array}$ & $\begin{array}{c}\alpha / \\
\alpha+c^{j}\end{array}$ \\
\hline 1 & WD-33 & 0.98 & 1.50 & 0.54 & 0.63 & 1.32 & 0.48 & 0.49 & 0.38 & 0.71 & 0.61 \\
\hline 2 & BED-4 & 0.41 & 1.48 & 0.65 & 0.64 & 1.29 & 0.29 & 0.49 & 0.35 & 0.53 & 0.60 \\
\hline 3 & GPT-SW & 0.69 & 1.30 & 0.74 & 0.66 & 1.48 & 0.40 & 0.43 & 0.41 & 0.56 & 0.59 \\
\hline 4 & Ram1 & 0.75 & 1.40 & 0.70 & 0.82 & 1.54 & 0.18 & 0.39 & 0.43 & 0.47 & 0.61 \\
\hline 5 & A-11 & 1.54 & 3.91 & 0.19 & 0.40 & 2.96 & 1.47 & 0.31 & 0.10 & 0.33 & 0.44 \\
\hline 6 & M. NE-15 & 1.51 & 3.61 & 0.16 & 0.37 & 2.78 & 1.79 & 0.35 & 0.09 & 0.31 & 0.41 \\
\hline 7 & M-16 & 1.55 & 3.51 & 0.17 & 0.42 & 3.30 & 1.50 & 0.33 & 0.09 & 0.31 & 0.49 \\
\hline 8 & $\mathrm{M}-25$ & 1.52 & 3.52 & 0.12 & 0.33 & 3.39 & 1.40 & 0.38 & 0.17 & 0.37 & 0.39 \\
\hline
\end{tabular}

Wax. $^{\text {a }}: \Sigma\left(n-\mathrm{C}_{21}-n-\mathrm{C}_{31}\right) / \Sigma\left(n-\mathrm{C}_{15}-n-\mathrm{C}_{20}\right)$

$\mathrm{Pr} / \mathrm{Ph}^{\mathrm{b}}$ Pristane/Phytane

$\mathrm{DBT} / \mathrm{PH}^{\mathrm{c}}$ : Dibenzothiophene/Phenanthrene

$\mathrm{C}_{35} / \mathrm{C}_{34}{ }^{\mathrm{d}}: \mathrm{C}_{35} / \mathrm{C}_{34}$ hopanes ( $\left.\mathrm{m} / \mathrm{z} 191\right)$

$\mathrm{C}_{29} / \mathrm{C}_{27}{ }^{\mathrm{e}}: \mathrm{C}_{29} \alpha \alpha \alpha$ 20R sterane/ $\mathrm{C}_{27} \alpha \alpha \alpha$ 20R sterane (m/z 217)

$\mathrm{C}_{29}$ Dia $^{\mathrm{f}}: \mathrm{C}_{29}$ diasterane/sterane (m/z 217)

$\% 20 \mathrm{~S}^{\mathrm{g}}: \mathrm{C}_{29} \alpha \alpha \alpha$ sterane $20 \mathrm{~S} /(20 \mathrm{~S}+20 \mathrm{R})(\mathrm{m} / \mathrm{z} 217)$

$\mathrm{C}_{29} / \mathrm{C}_{30}{ }^{\mathrm{h}}: \mathrm{C}_{29} \alpha \alpha \alpha$ sterane-R/ $\mathrm{C}_{30}$ hope $(\mathrm{m} / \mathrm{z} 217, \mathrm{~m} / 191)$

$T s /(T s+T m)^{\mathrm{i}}: 18 \alpha(\mathrm{H})-22,29,30$-trisnorneohopane $/(18 \alpha(\mathrm{H})-22,29,30$-trisnorneohopane $+17 \alpha(\mathrm{H})-22,29,30-$

trisnorhopane) $(\mathrm{m} / \mathrm{z} 217)$

$\alpha / \alpha+c^{j}$ : benzo $[\alpha]$ carbazole / (benzo $[\alpha]$ carbazole + benzo $[c]$ carbazole)

Full scan mass spectra were recorded over the mass range of 150 to $300 \mathrm{Da}$ at a scan rate of $1 \mathrm{~s}$ per decade, an inter scan time of $0.2 \mathrm{~s}$ and a scan cycle time of $0.5 \mathrm{~s}$. Identification of individual carbazoles and benzocarbazoles was based on comparison with authentic standards and literature data (Bowler et al., 1997). Quantification was performed using $\mathrm{N}$-phenylcarbazole as an internal standard taking into account all significant fragment ions of the target compounds. 


\section{Results and Discussions}

\section{General Characteristics}

A complete characterization of bulk properties (API and sulphur contents), $n$-alkanes, pristane, phytane, biomarkers steranes and hopanes, and aromatics (phenanthrenes, dibenzothiophenes) of the Abu Gharadig and Shushan crude oil samples have been reported in details elsewhere (Bakr, this issue). In this study, the molecular parameters used in relation to the variability of the pyrrolic nitrogen compounds, will be briefly discussed. As given in Table 1, typically, nonwaxy characters, enhanced $\mathrm{C}_{35}$ homohopanes, low diasterane content, high sterane/hopane values, low $\mathrm{Pr} / \mathrm{Ph}$, in combination with relatively high values of DBT/PHEN and $T s / T s+T m$ were observed for the Abu Gharadig crude oil samples. These geochemical parameters indicate that Abu Gharadig oils were sourced from marine shale of Type II deposited in suboxic environment. Compared with the Abu Gharadig, the Shushan oil samples are waxy in nature and showed some significantly different characteristics. These differences are represented by lower $\mathrm{C}_{35}$ homohopanes, lower sterane/hopane values, and a strong dominance of $\mathrm{C}_{29}$ over $\mathrm{C}_{27}$ steranes, higher $\mathrm{Pr} / \mathrm{Ph}$, and lower DBT/PHEN (Table 1). All these features are considered typical of oil generated from clay-rich terrigenous source rocks that received greater higher plant input, and are likely generated from type III-II sources deposited under oxic conditions.

\section{Occurrence and Distribution of Carbazoles}

Concentrations of Carbazoles $\left(C_{0^{-}} C_{2}\right)$

Carbazole is a tricyclic aromatic nitrogen compound which may be alkylated and annelated to form two main series of derivatives, namely alkylated carbazoles and alkylated benzo- and dibenzocarbazoles. The concentrations of carbazole, individual alkyl- carbazoles and the benzo[a]- and benzo [c] carbazoles in the studied oil samples are given in Table 2. The codes used for the assignment of carbazoles and benzocarbazoles are presented in Table 3. 


\begin{tabular}{|c|c|c|c|c|c|c|c|c|c|c|}
\hline U్ర & $\tilde{0}$ & $\stackrel{t}{0}$ & t) & & $\ddot{\circ}$ & $\frac{\infty}{0}$ & $\stackrel{\Xi}{a}$ & & $\stackrel{0}{\stackrel{0}{0}}$ & के \\
\hline U్ల్ల & $\stackrel{2}{2}$ & గ్రి & वे & & $\stackrel{0}{\circ}$ & $\stackrel{2}{\circ}$ & $\frac{1}{c}$ & & $\begin{array}{l}0 \\
0 \\
0\end{array}$ & $\frac{m}{0}$ \\
\hline $\mathscr{\sim}$ & $\begin{array}{l}\circ \\
\infty \\
0\end{array}$ & ڤ్ & $\stackrel{\circ}{\infty}$ & & $\frac{9}{0}$ & $\hat{\circ}$ & $\frac{7}{2}$ & & $\frac{9}{0}$ & $\frac{n}{0}$ \\
\hline$\stackrel{\sim}{\sim}$ & ț & ஜֶ: & g & & તิ & $\stackrel{\circ}{0}$ & $\frac{9}{c}$ & & $\frac{7}{0}$ & ฮุ \\
\hline$\simeq$ & $\grave{\widehat{o}}$ & ֶิ & $\stackrel{\infty}{\tilde{c}}$ & & $\stackrel{\infty}{0}$ & ¿̊. & $g$ & & ¿a. & $\frac{0}{0}$ \\
\hline$\approx$ & fof & 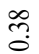 & ? & & f․ & ¿̊. & g & & $\stackrel{0}{0}$ & ज: \\
\hline$\stackrel{\sim}{\sim}$ & ఫे & $\stackrel{\infty}{\infty}$ & 호 & & ָ̃ & $\frac{m}{0}$ & $\tilde{c}$ & & ֶิ & ঙุ \\
\hline 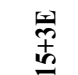 & $\begin{array}{c}\infty \\
i \\
i\end{array}$ & $\stackrel{g}{g}$ & $\tilde{n}$ & & กิ & กิ & If & & $\tilde{ก}$ & ?̊ \\
\hline $\begin{array}{l}\text { 罣 } \\
\text { 寺 }\end{array}$ & $\stackrel{\Omega}{\Omega}$ & gq. & $\stackrel{8}{\circ}$ & & ఫ. & กี & J & & $\underset{\sigma}{\vec{f}}$ & గి \\
\hline$=$ & $\stackrel{\overbrace a}{\sim}$ & 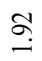 & $\stackrel{2}{2}$ & & $\stackrel{\infty}{n}$ & 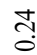 & จ & & ñ & $\begin{array}{l}0 \\
n \\
0\end{array}$ \\
\hline 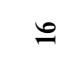 & $\cong$ & 守 & 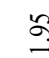 & & รั. & $\stackrel{0}{0}$ & cి & & $\stackrel{?}{\tilde{c}}$ & के \\
\hline$\cong$ & 气ุ & $\stackrel{\overbrace{}}{q}$ & $\propto$ & & $\stackrel{0}{=}$ & $\overline{\mathrm{S}}$ & g & & $\sqrt{n}$ & ڤి \\
\hline 되= & F. & $\frac{0}{0}$ & $\approx$ & & $\ddot{\circ}$ & 웅. & $\bar{a}$ & & ปี & $\stackrel{\text { ஸे }}{0}$ \\
\hline$\stackrel{\infty}{2}$ & 茓 & $\underset{-\infty}{\infty}$ & ๙ิ & & $\underset{d}{+}$ & $\stackrel{\sharp}{0}$ & 7 & & $\tilde{\tilde{o}}$ & 웅 \\
\hline$\sigma$ & $\stackrel{\infty}{\stackrel{\sim}{i}}$ & $\Xi$ & g & & กี & ?ั? & $\stackrel{0}{0}$ & & $\vec{\sigma}$ & $\stackrel{2}{8}$ \\
\hline$N$ & $\underset{ָ}{\widetilde{N}}$ & $\stackrel{\infty}{=}$ & กิ & & ఫे & $\stackrel{0}{0}$ & ฮิ & & ปั & กิ \\
\hline$m$ & 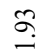 & $\stackrel{ \pm}{ \pm}$ & $\stackrel{t}{\circ}$ & & זั & $\stackrel{2}{0}$ & $\frac{\circ}{c}$ & & ஸి & $\stackrel{2}{0}$ \\
\hline- & $\underset{+}{\sigma}$ & సેㄱ & $\stackrel{尺}{\stackrel{2}{2}}$ & & $\frac{⿱}{\sigma}$ & $\stackrel{\sim}{\sim}$ & g & & gे. & 웅. \\
\hline U & $\underset{i}{8}$ & $\stackrel{0}{\circ}$ & $\stackrel{2}{\sigma}$ & & F. & $\frac{n}{0}$ & $\frac{9}{c}$ & & $\begin{array}{l}0 \\
\stackrel{0}{0}\end{array}$ & $\frac{ \pm}{0}$ \\
\hline $\bar{\sigma} \overline{\overline{0}}$ & $\hat{\hat{\beta}}$ & 芒 & 它 & 家 & 䓌 & $\bar{z}$ & 岁 & $c$ & $\frac{0}{\dot{1}}$ & $\begin{array}{l}\stackrel{2}{s} \\
\stackrel{s}{\Sigma}\end{array}$ \\
\hline 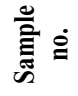 & - & $\sim$ & $m$ & & 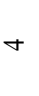 & in & 6 & & $r$ & $\infty$ \\
\hline
\end{tabular}


Table 3. The codes used for the assignment of carbazoles and benzocarbazoles in Table 2.

\begin{tabular}{|l|l|}
\hline Code & \multicolumn{1}{|c|}{ Compound } \\
\hline $\mathrm{C}$ & carbazole \\
1 & 1-methylcarbazole \\
3 & 3-methylcarbazole \\
2 & 2-methylcarbazole \\
4 & 4-methylcarbazole \\
18 & 1,8-dimethylcarbazole \\
$1 \mathrm{E}$ & 1-ethylcarbazole \\
13 & 1,3-dimethlycarbazole \\
16 & 1,6-dimethylcarbazole \\
17 & 1,7-dimethylcarbazole \\
14 & 1,4-dimethylcarbazole \\
$4 \mathrm{E}$ & 4-ethylcarbazole \\
15 & 1,5-dimethylcarbazole \\
$3 \mathrm{E}$ & 3-ethylcarbazole \\
26 & 2,6-dimethylcarbazole \\
27 & 2,7-dimethylcarbazole \\
12 & 1,2-dimethylcarbazole \\
24 & 2,4-dimethylcarbazole \\
25 & 2,5-dimethylcarbazole \\
$\mathrm{BaC}$ & benzo[a]carbazole \\
$\mathrm{BcC}$ & benzo[c]carbazole \\
\hline
\end{tabular}

An extracted ion chromatogram displaying the distribution of the $\mathrm{C}_{0}-\mathrm{C}_{2}$ carbazoles in a representative crude oil sample is displayed in Fig. 2. The present study shows that the concentration of individual pyrrolic nitrogen compounds (homologues $\mathrm{C}_{0}-\mathrm{C}_{2}$ ) is significantly different in the Abu Gharadig and Shushan oils, and it is suitable for differentiating the samples related to the two basins. Figure 3 displays in $\mu \mathrm{g} / \mathrm{g}$ oil, the different concentration ranges of $\mathrm{C}_{0}-\mathrm{C}_{2}$ carbazoles for the studied crude oil samples. Overall, the highest yields of carbazole, methylcarbazoles and dimethylcarbazoles were recognized in the $\mathrm{Abu}$ Gharadig oils, whereas Shushan oils exhibit lowest concentrations of $\mathrm{C}_{0}-\mathrm{C}_{2}$ carbazoles. In Abu Gharadig crude oils, carbazole, summed methyl carbazole and 


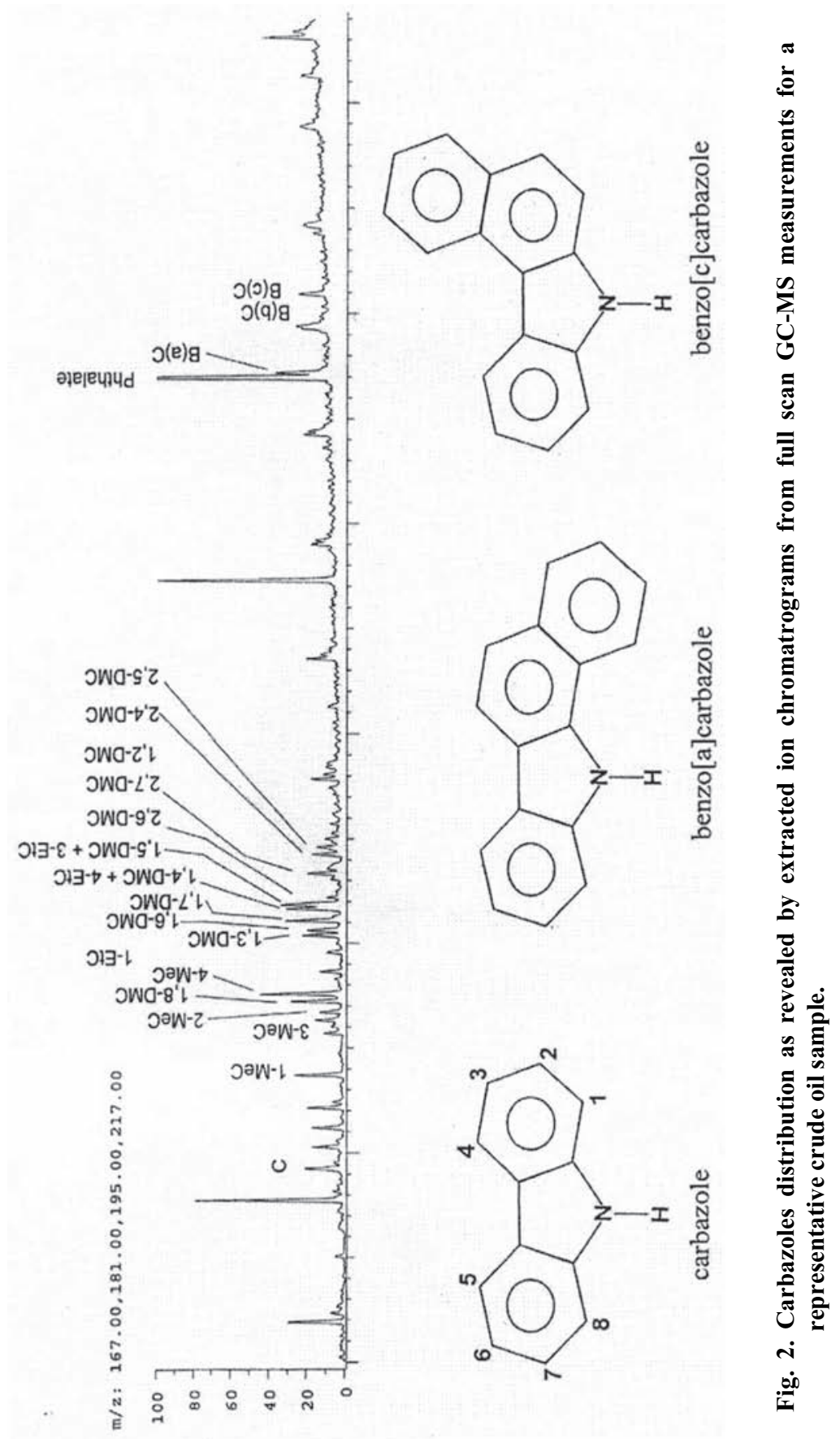



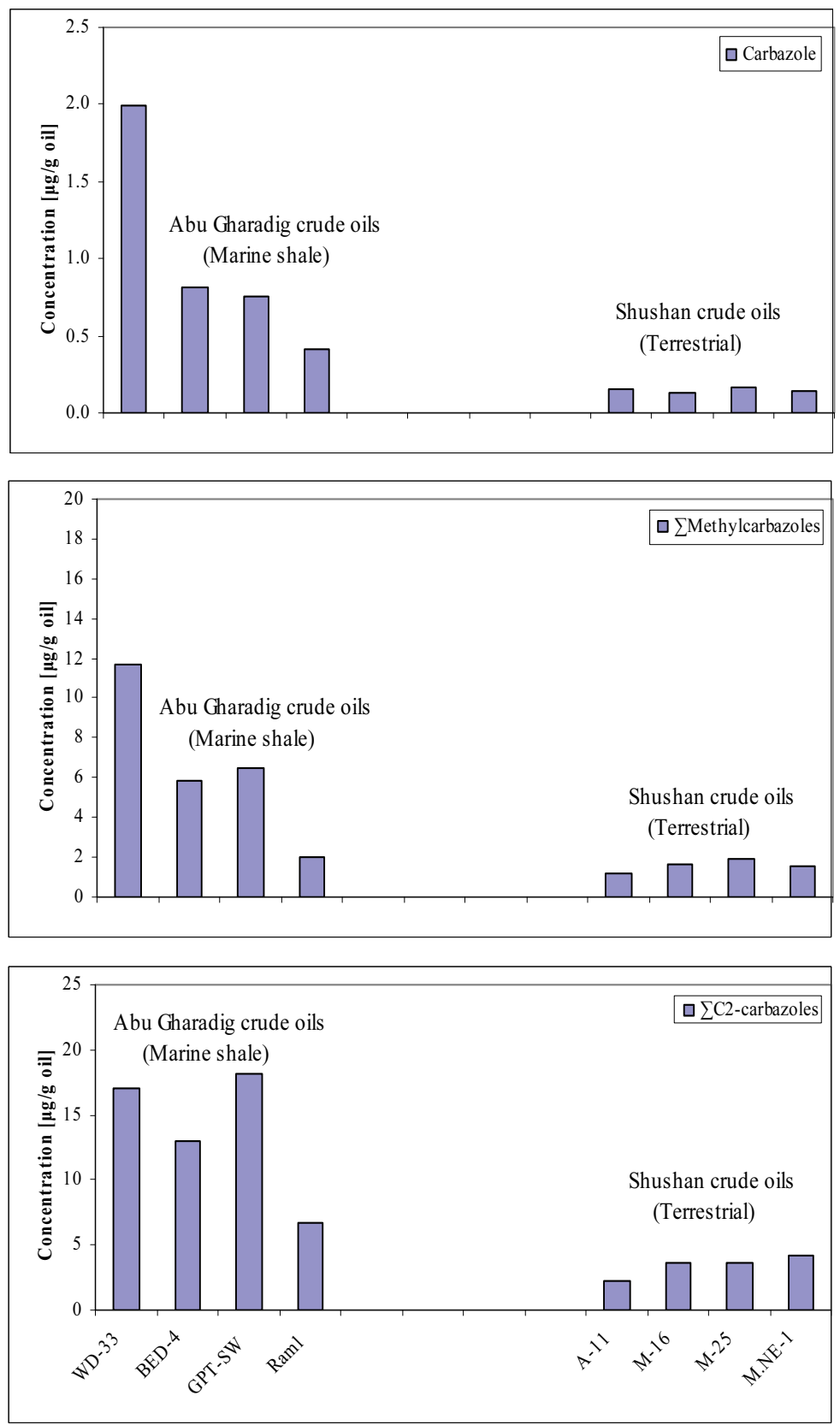

Fig. 3. Concentrations of carbazoles in crude oil samples from the Abu Gharadig and Shushan basins. 
summed $\mathrm{C}_{2}$-carbazole concentrations range from 0.41 to $2.0,2.01$ to 11.73 and 6.68 to $18.19 \mu \mathrm{g} / \mathrm{g}$ oil, respectively. Whereas in Shushan oils, carbazole, summed methyl carbazole and summed $\mathrm{C}_{2}$-carbazole concentrations range from 0.13 to $0.16,1.17$ to 1.94 and 2.20 to 4.24 $\mu \mathrm{g} / \mathrm{g}$ oil, respectively.

These findings provide evidence that the occurrence and distributions of pyrrolic nitrogen compounds is controlled by source characteristics of the studied samples. It is noteworthy that the yields determined here for the Abu Gharadig (marine shale) and Shushan (terrestrial) crude oils are significantly lower than those of the crude oils from Gulf of Suez (marine carbonate) (Bakr and Wilkes, 2002).

\section{Compositions of Carbazoles}

$C_{1}$-Carbazoles

All four methylcarbazole isomers 1-, 3-, 2-, and 4-methylcarbazoles are present in the studied oil samples (Table 2). For the Abu Gharadig oils, 1-methylcarbazole is the most abundant methylcarbazole and 3methylcarbazole is the least abundant (Table 2). As for the Shushan oils, 4-methylcarbazole is the most abundant and 3-methylcarbazole is the least abundant methylcarbazole. In the work of Dorbon et al. (1984) on crude oils and Li et al. (1995) for source rocks, it was reported that 4methylcarbazole is the most abundant and 1-methylcarbazole is the least abundant methylcarbazole.

Triangular diagrams have been used previously to evaluate variations of the alkylcarbazoles (Li et al., 1995; Clegg et al., 1997, 1998a,b; Horsfield et al., 1998). The distributions of the methylcarbazoles, 1-, 3+2-, and 4- are shown in a ternary plot after Li et al. (1995) (Fig. 4A). This figure demonstrates that the two oil families Abu Gharadig and Shushan are well differentiated on the basis of the methylcarbazole distribution. Abu Gharadig oils have higher values of 1methylcarbazole and 3+2-methylcarbazoles than Shushan oils. On the other hand, significantly higher relative amounts of 4-methylcarbazole $(\sim 50 \%)$ were found in the Shushan oil samples. In Abu Gharadig oil samples, 1-methylcarbazole, 3+2-methylcarbazoles and 4-methylcarbazole range from 37 to 41,35 to 39 and 20 to $26 \%$ of the total 
methylcarbazoles, respectively. As for Shushan oil samples, 1methylcarbazole, 3+2-methylcarbazoles and 4-methylcarbazole range from 24 to 26,23 to 26 and 50 to $52 \%$ of the total methylcarbazoles, respectively. Previously it was reported that immature $\left(\sim 0.5 \% R_{\mathrm{o}}\right)$ and mature $\left(\sim 0.8 \% R_{0}\right)$ Lower Keg River carbonates as well as Posidonia Shale samples of different maturity $\left(0.48-1.45 \% \quad R_{\mathrm{o}}\right)$ could be discriminated in this plot (Clegg et al., 1997, 1998b). Furthermore, Li et al. (1995) had earlier shown that even stronger variations of the methylcarbazoles occurred in a data set based on a much broader selection of crude oil and source rock samples. It may be concluded that the methylcarbazoles are well suited for the differentiation of Abu Gharadig and Shushan crude oils with respect to geographical origin and variations of facies and depositional environment. Most likely, source rock type of the two oil families appears to play an important role in controlling carbazole distributions. This is probably being indicative of differences in kerogen type and mechanisms of primary migration.

\section{$C_{2}$-Carbazoles}

Dimethylcarbazoles are abundant in all the studied oil samples. Partially shielded carbazoles, i.e. one alkyl group present at the 1position (Li et al., 1995) are dominant. This includes dominance of carbazoles containing isomers with methyl groups at the 1,8-positions and 1-position, e.g. 1,8-dimethylcarbazole, 1,3-dimethylcarbazole, 1,6dimethylcarbazole, 1,7- dimethylcarbazole, 1,4-dimethylcarbazole and 1,5- dimethylcarbazole (for simplicity, the 1,4- and 1,5-dimethylcarbazoles are referred to the corresponding peaks in Fig. 2, despite their co-elution with 4-ethylcarbazole and 3-ethylcarbazole, respectively). A ternary plot of the relative abundances of 1,8-, 2,7- and 1,3dimethylcarbazoles representing so called shielded, exposed and partially shielded carbazoles is illustrated in Fig. 4B. As can been observed, the relative abundance of 1,8- dimethylcarbazoe ranges from 36 to $62 \%$, with relatively high values (ca. $>51 \%$ ) in all Abu Gharadig oil samples and low values (ca. $<51 \%$ ) in all Shushan samples. The relative amount of 1,3-dimethylcarbazole ranges from 30 to $55 \%$, with relatively high values (ca. $>43 \%$ ) in all Shushan oil samples and low values (ca. $<43 \%$ ) in all Abu Gharadig samples. All oil samples from the two basins are characterized by low relative amounts of 2,7-dimethylcarbazole with an 


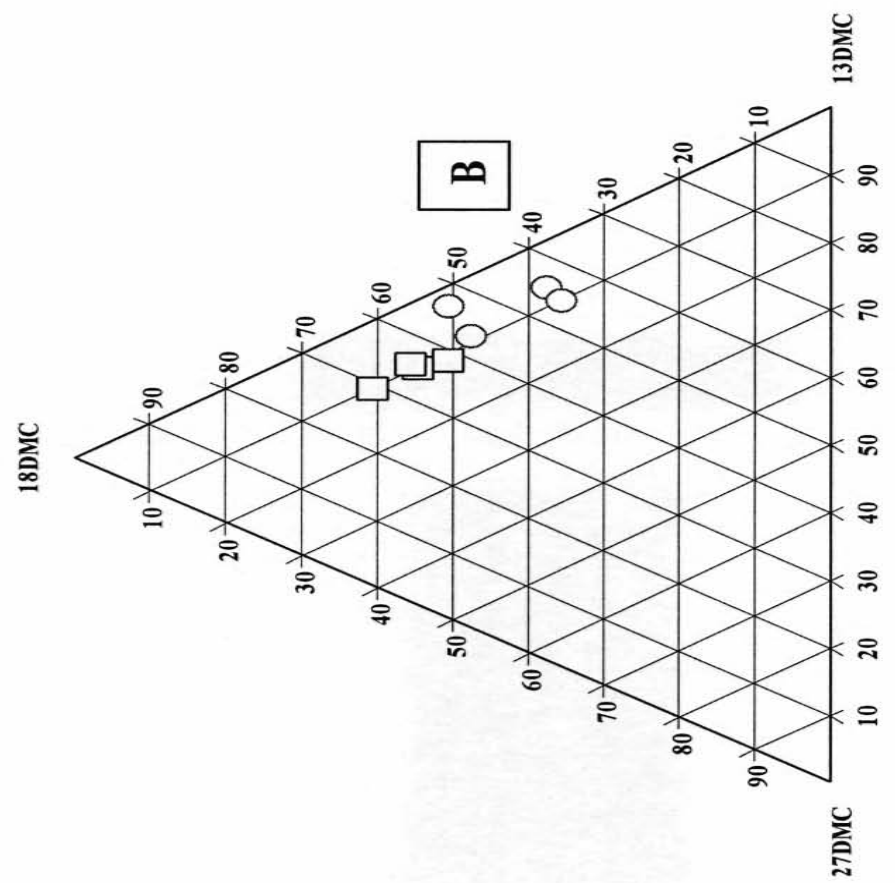

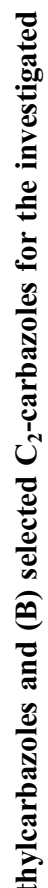

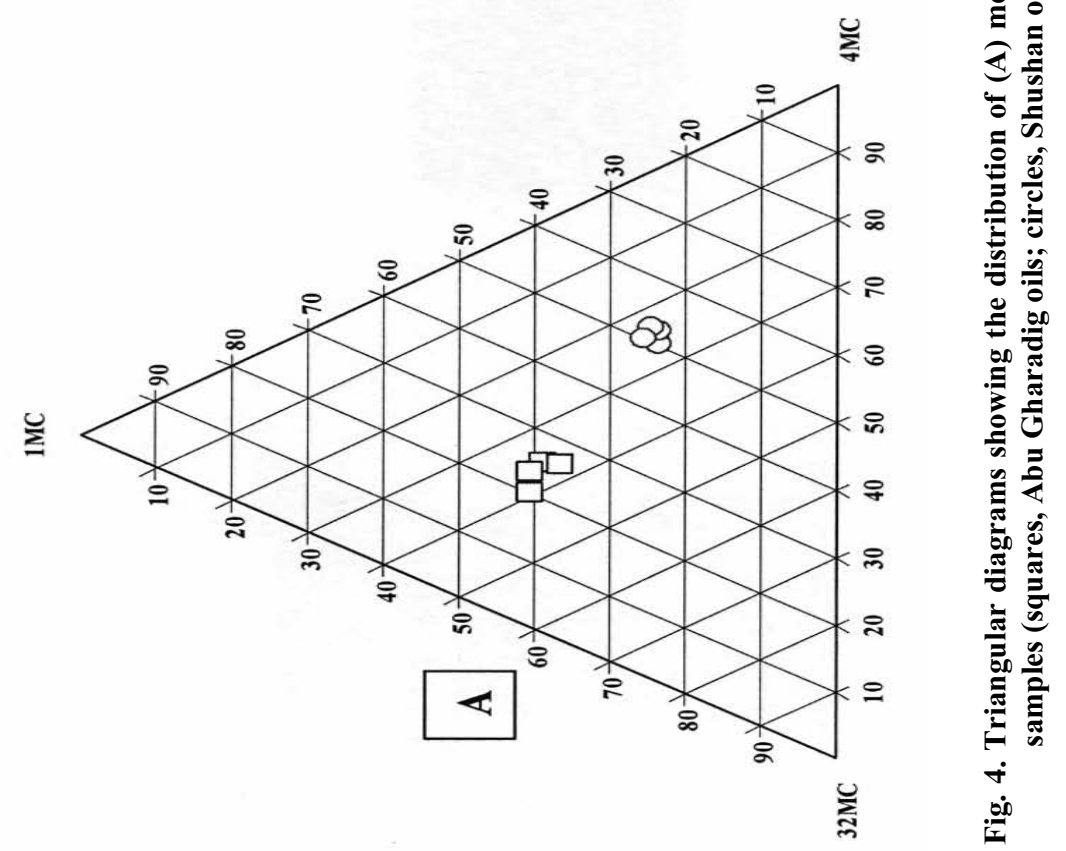


average value of $7 \%$ of the total dimethylcarbazoles. Most likely, the most significant differences between the oil samples of the two basins seem to be the relative amounts of 1,3- dimethylcarbazole and 1,8dimethylcarbazole instead of 2,7-dimethylcarbazole. As compared to the $1-, 3+2$, and 4-methylcarbazoles plotted in the ternary diagram shown in Fig. 4A, the variations in the relative amounts of 1,8-, 1,3- and 2,7dimethylcarbazoles could also differentiate between crude oils of the two basins (Fig. 4B).

\section{Carbazole Distribution and Maturity}

Maturation effects on carbazole distributions in crude oils and source rocks have been noted previously (Clegg et al., 1998b; Harrison et al., 1997; Li et al., 1997; and Horsfield et al., 1998), where maturity covered a considerable span. Clegg et al. (1997) compared the immature Lower Keg River Member wackestones with the immature Upper Keg River Member marlstones from the La Crete sub-basin in western Canada in order to investigate the possible lithofacies dependency of pyrrolic nitrogen compound distributions. These authors considered the source of the pyrrolic nitrogen compounds to be facies dependent, although they did not exclude primary expulsion at very early stages of thermal maturation as another possible alternative explanation to the observed pyrrolic nitrogen compound distributions. In contrast, Li et al. (1999) in their studies on samples from the same area could not detect clear differences in the distributions of alkylcarbazoles and benzocarbazoles among the end member oils.

In this study, the maturation parameter based on the isomerization at C-20 in the $\mathrm{C}_{29} \alpha \alpha \alpha$ steranes $(20 \mathrm{~S} / 20 \mathrm{~S}+20 \mathrm{R})$ indicates a high maturity level biased towards Abu Gharadig oils (Table 1). Several alkylcarbazole parameters previously thought to be maturity related (e.g., Clegg et al., 1998b; Li et al., 1997) are plotted against the biomarker maturity parameter $\mathrm{C}_{29} \quad \alpha \alpha \alpha$ steranes $(20 \mathrm{~S} / 20 \mathrm{~S}+20 \mathrm{R})$ in Fig. 5. These alkylcarbazole parameters include $1 \mathrm{MC} / 1 \mathrm{MC}+1 \mathrm{EC}, 3 \mathrm{MC} / 4 \mathrm{MC}$ and 18DMC/18DMC+1EC.

Although a slight increase or decrease in some of these parameters with increasing biomarker maturity $\mathrm{C}_{29} \alpha \alpha \alpha$ steranes (20S/20S+20R) 

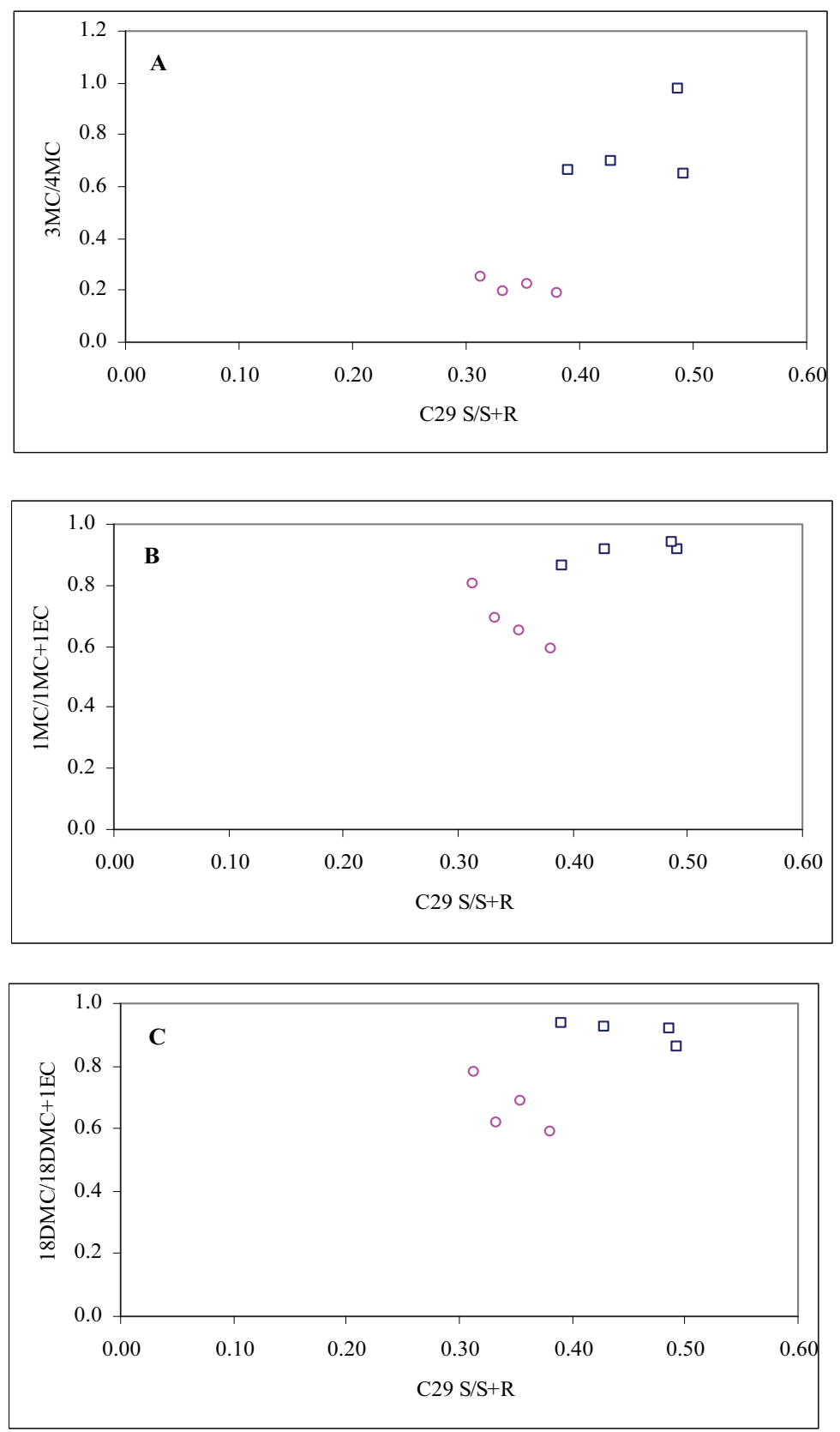

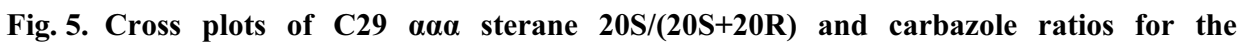
investigated samples (squares, Abu Gharadig crude oils; circles, Shushan crude oils). 
ratio may be present, the differences of carbazole ratios between the two basins do not show a direct maturity-dependence despite a considerable maturation span. Therefore, these observations may indicate that thermal maturation can be ruled out as a major factor in controlling the changes in the carbazole ratios in the crude oil samples of the Abu Gharadig and Shushan basins.

As the chemical structures of alkylcarbazoles are similar to those of the alkyl dibenzothiophenes, Clegg et al. (1998b) suggested that alkylcarbazoles may be formed through alkylation of the parent compound and interconversion of isomers in similar ways to those proposed for dibenzothiophenes (Radke et al., 1982), phenanthrenes (Alexander et al., 1995) and phenols (Ioppolo- Armanios et al., 1994). This suggestion may be quite plausible if potential source rocks across a wide range of thermal maturity are concerned, e.g. in the Gulf of Mexico (Clegg et al., 1998b). However, the effects of thermal maturation on the alkylcarbazole distribution in the reservoired oil (which are normally generated within a relatively narrow maturity window for any given source rock) are clearly less pronounced than those on the distributions of saturated hydrocarbon biomarkers, aromatic hydrocarbons and sulphur-heterocyclic aromatics. Similar observations have been made previously from various crude oils in a relatively closed petroleum system in Alberta (Li et al., 1999).

\section{Carbazole Distributions and Environments, and Source-Dependency}

The different depositional environments were clearly indicated from biomarker signatures, such as $\mathrm{Pr} / \mathrm{Ph}, \mathrm{C}_{35} / \mathrm{C}_{34}$ homohopanes and sterane/hopane ratios (Table 1). Cross plots of the alkylcarbazoles $1 \mathrm{MC} / 1 \mathrm{MC}+1 \mathrm{EC}, 3 \mathrm{MC} / 4 \mathrm{MC}$ and $18 \mathrm{DMC} / 18 \mathrm{DMC}+1 \mathrm{EC}$ versus $\mathrm{Pr} / \mathrm{Ph}$ (Fig. 6), waxiness (Fig. 7) and $\mathrm{C}_{29} / \mathrm{C}_{27}$ steranes (Fig. 8) when applied to the studied crude oil samples serve to distinguish two main types of depositional setting; terrestrial dominated source deposited in oxidizing conditions for the Shushan oils and marine shale dominated sourced oil deposited in suboxic environments for the Abu Gharadig samples. Shushan oil samples are dominated by $\mathrm{C}_{29} / \mathrm{C}_{27}$ sterane ratios, and are characterized by higher $\mathrm{Pr} / \mathrm{Ph}$, higher waxiness, and lower alkylcarbazoles concentrations than Abu Gharadig oils (Tables 1 and 2). 

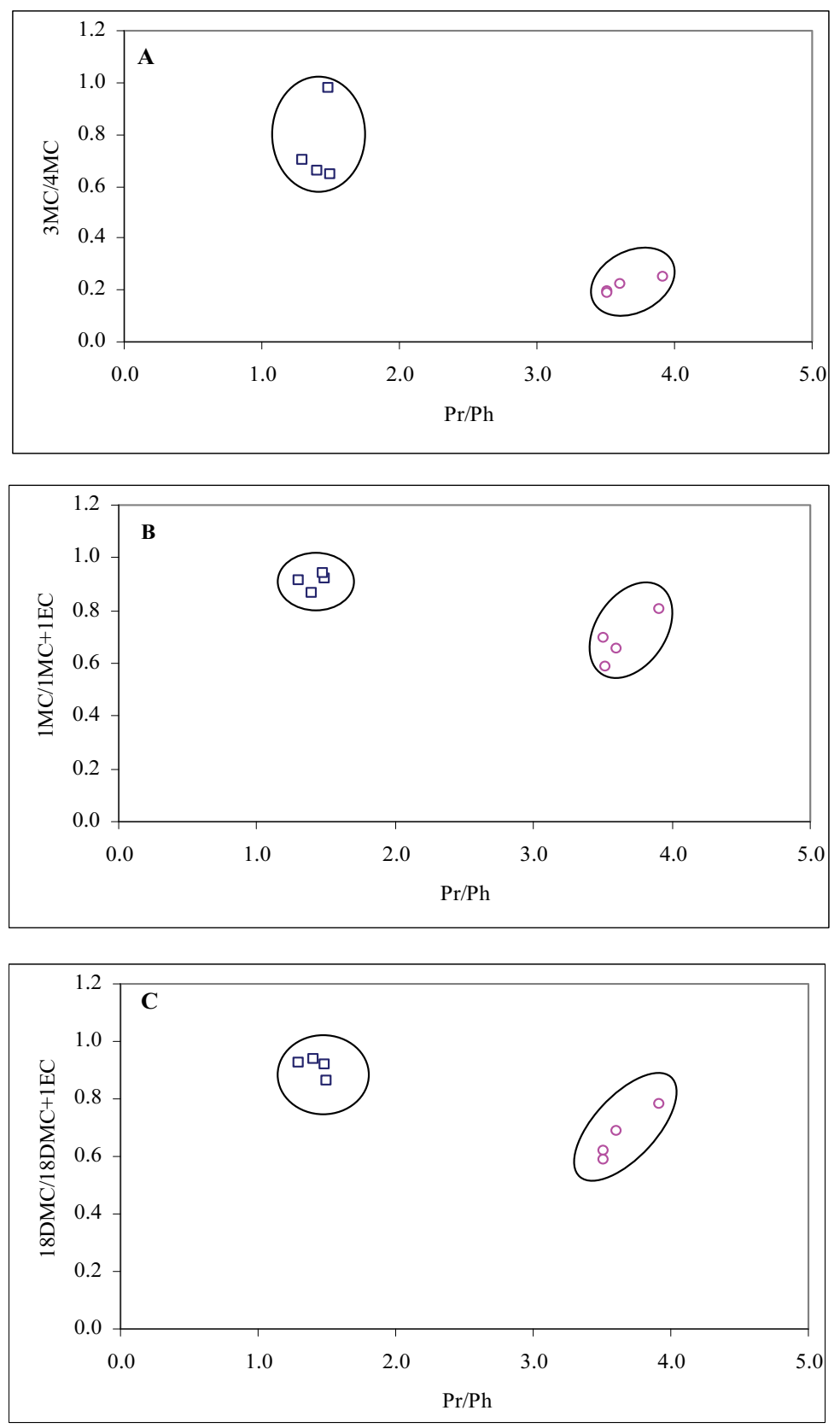

Fig. 6. Cross plots of $\mathrm{Pr} / \mathrm{Ph}$ and carbazole ratios for the investigated samples (squares, Abu Gharadig crude oils; circles, Shushan crude oils). 

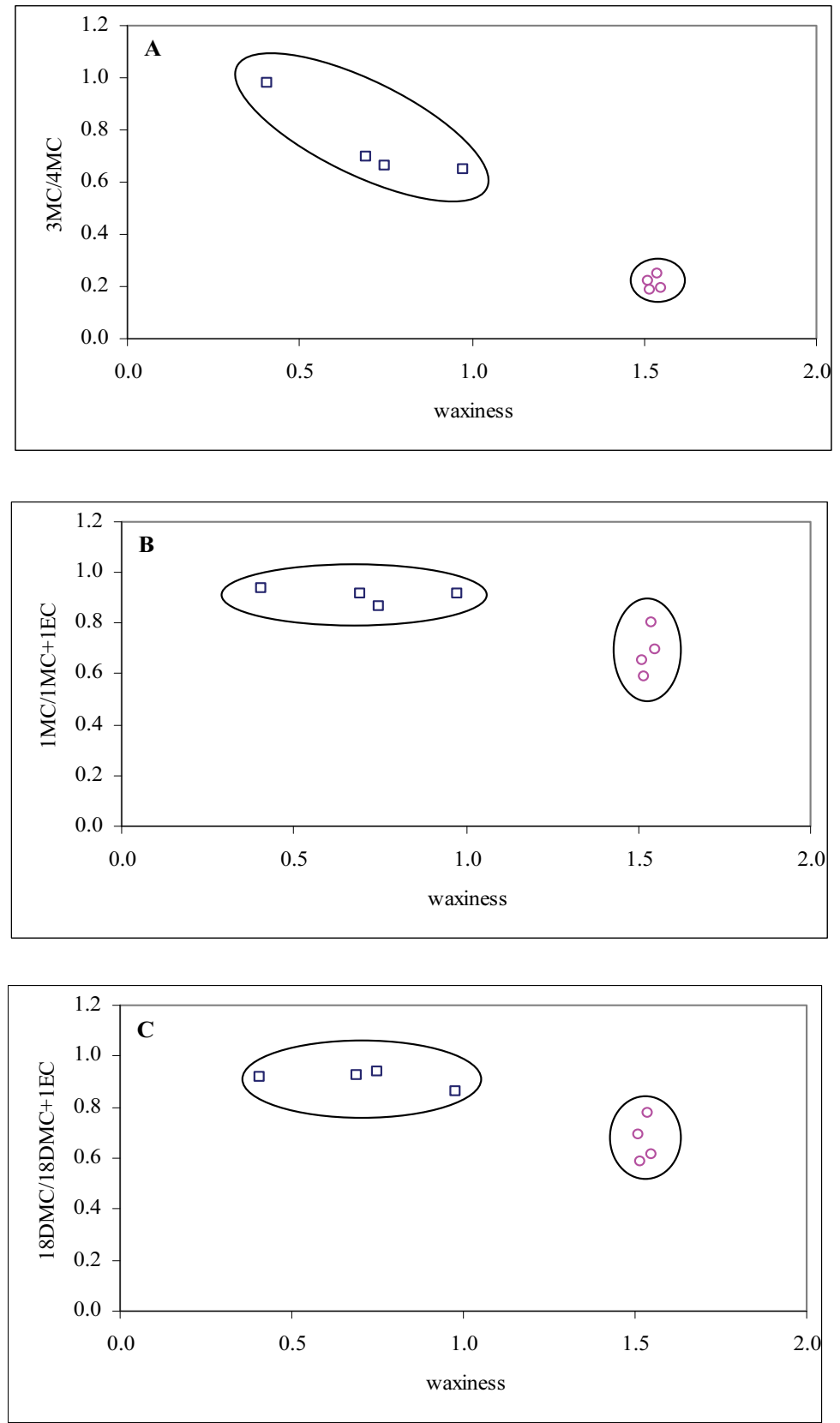

Fig. 7. Cross plots of waxiness $\sum\left(n-\mathrm{C}_{21}-n-\mathrm{C}_{31}\right) / \sum\left(n-\mathrm{C}_{15}-n-\mathrm{C}_{20}\right)$ and carbazole ratios for the investigated samples (squares, Abu Gharadig crude oils; circles, Shushan crude oils). 

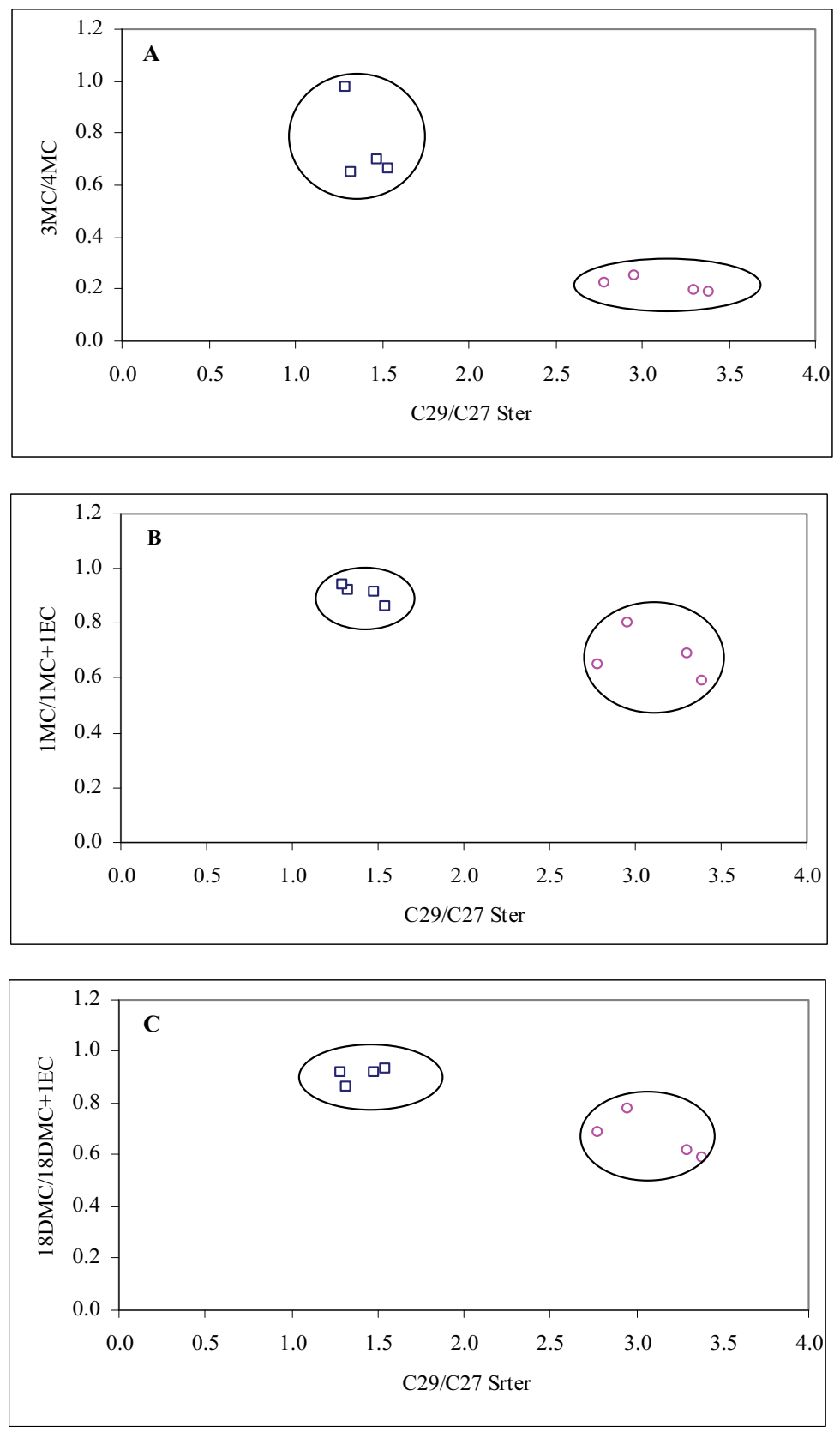

Fig. 8. Cross plots of $C_{29} \alpha \alpha \alpha 20 R$ sterane/C $C_{27} \alpha \alpha \alpha 20 R$ sterane and carbazole ratios for the investigated samples (squares, Abu Gharadig crude oils; circles, Shushan crude oils). 
These differences observed between the Abu Gharadig and Shushan oils must be a reflection of the differences in the depositional environment and/or organic input into their source rocks. The Abu Gharadig and Shushan oil groups are also clearly differentiated in Fig. 9. The terrestrially sourced Shushan oils, generally have relatively low values of $1 \mathrm{MC} / 1 \mathrm{MC}+1 \mathrm{EC}, 3 \mathrm{MC} / 4 \mathrm{MC}$ and $18 \mathrm{DMC} / 18 \mathrm{DMC}+1 \mathrm{EC}$ ratios, as compared to the marine clastic sourced Abu Gharadig crude oils. All these observations may indicate that the alkylcarbazole distributions, with significant variations between 1-, 3-, 4-methylcarbazoles, and 1,8dimethylcarbazoles, may have strong environment dependence, based on the limited number of samples investigated here from the different depositional conditions in the two basins.

\section{Benzocarbazoles}

\section{Occurrence and Distribution af Benzocarbazoles}

The concentrations of the benzocarbazole isomers in the studied crude oil samples are low (Table 2). Benzo[b]carbazole was near or even below the detection limit in many samples. The ratio benzo[a] to benzo[c] carbazoles $[a /(a+c)]$ covers a range from 0.39 to 0.61 for the studied crude oil samples (Table 1). A noteworthy feature is that the variability of $a /(a+c)$ in this study is less than the range of variability, which has been reported earlier in facies and depositional environment, migration, and maturity related case studies (Larter et al., 1996; Clegg et al., 1998b; Horsfield et al., 1998; Bakr and Wilkes, 2002).

The benzocarbazoles $a /(a+c)$ ratio for the studied samples is plotted relative to source maturity indicator, $\mathrm{C}_{29} \alpha \alpha \alpha$ steranes $(20 \mathrm{~S} / 20 \mathrm{~S}+20 \mathrm{R})$, in Fig. 10A. The scatter among the data points overshadows any control that maturity might have on these oils. Other factors effects may be important contributors in determining benzocarbazole distributions in the Western Desert crude oils. The results from this study suggest that maturity effects may be subordinate to other factors.

The behavior of the benzocarbazole $a /(a+c)$ parameter is considered in terms of palaeoenvironmental conditions, $\mathrm{Pr} / \mathrm{Ph}$ (Fig. 10B), source and waxiness (Fig. 10C), and $\mathrm{C}_{29} / \mathrm{C}_{27}$ sterane (Fig. 10D). From Fig. 10B-D, the benzocarbazole $a /(a+c)$ reveals geographical correspondence emerging where the highest and lowest $a /(a+c)$ values are found in Abu 

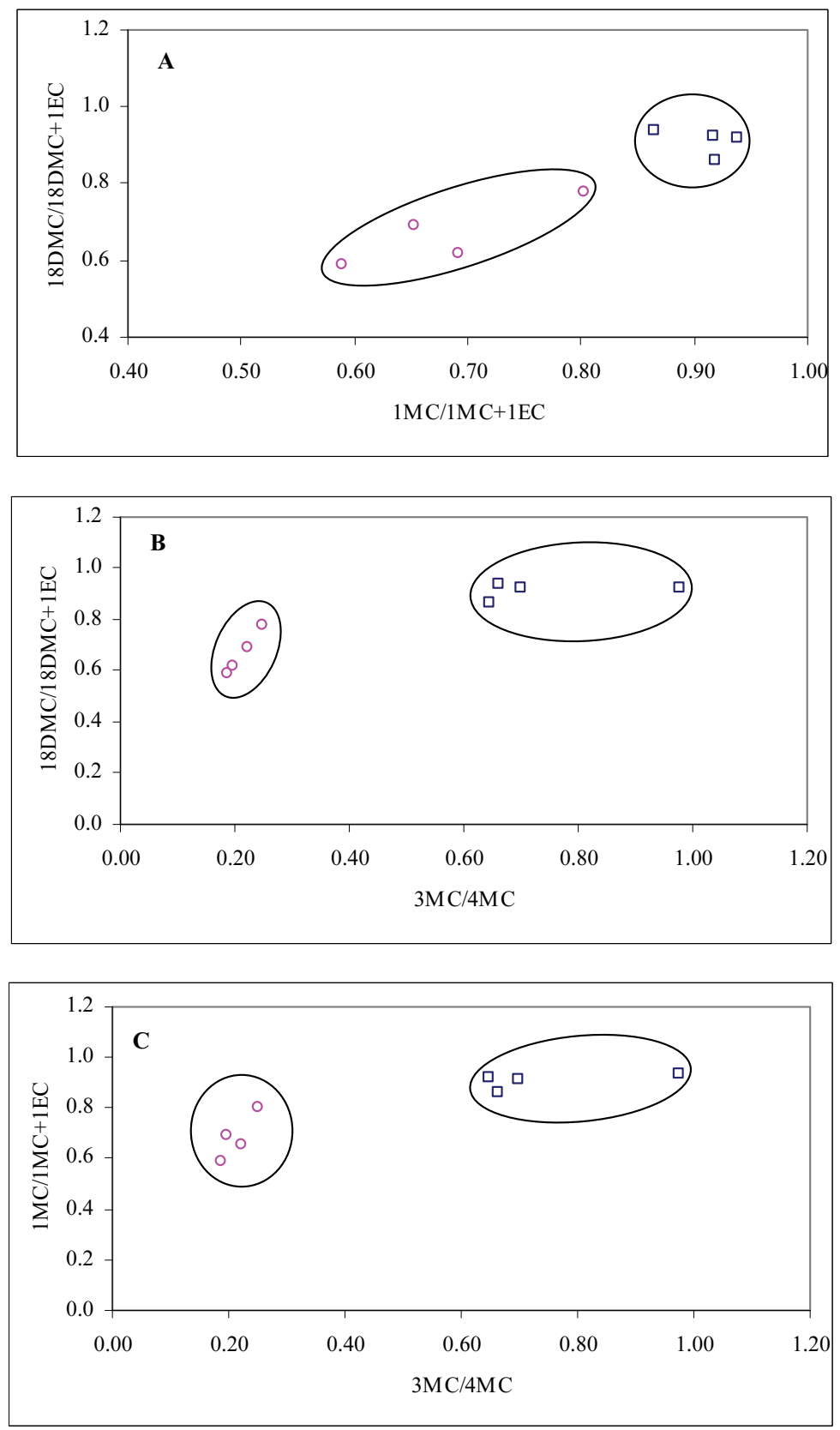

Fig. 9. Cross plots of $C_{1}$ - and $C_{2}$-carbazole ratios for the investigated samples (squares, $A b u$ Gharadig crude oils; circles, Shushan crude oils). 
Occurrence and Geochemical Significance of Carbazoles...
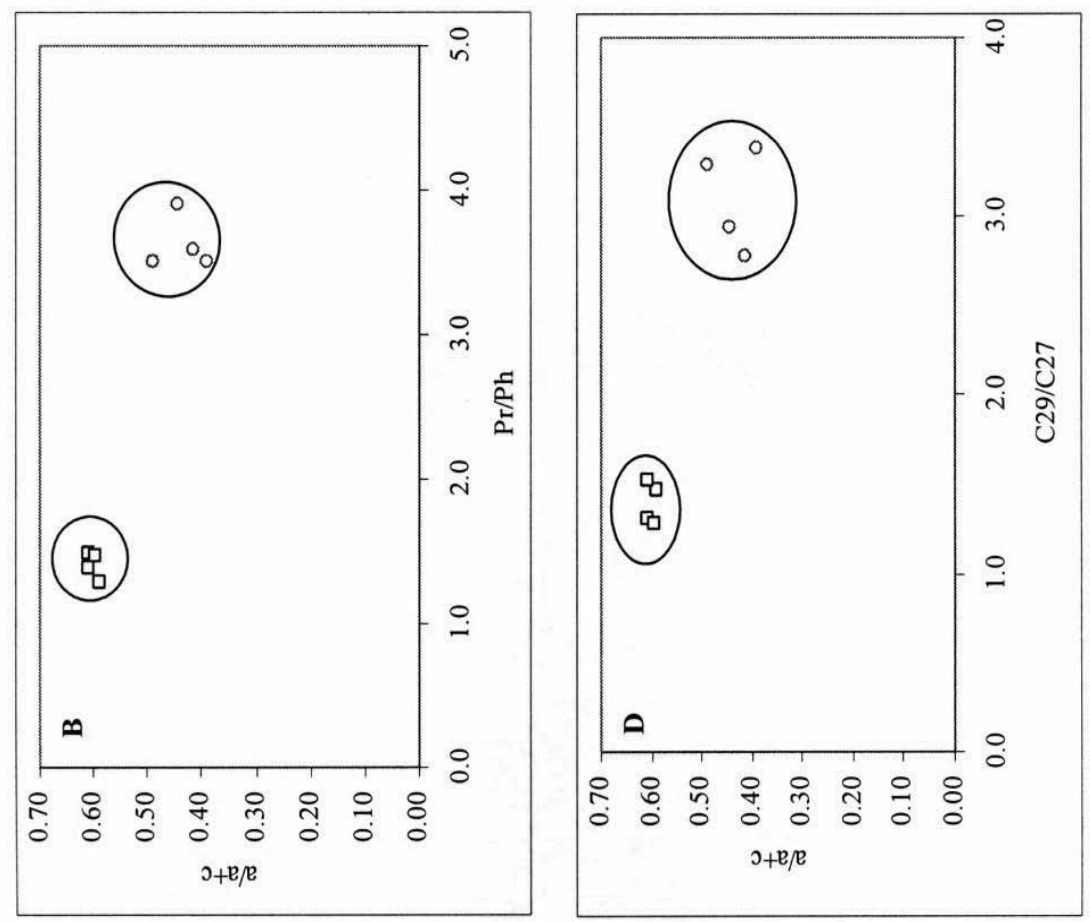

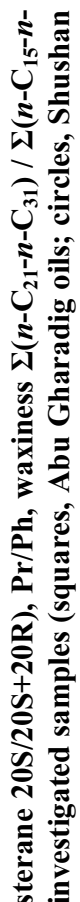
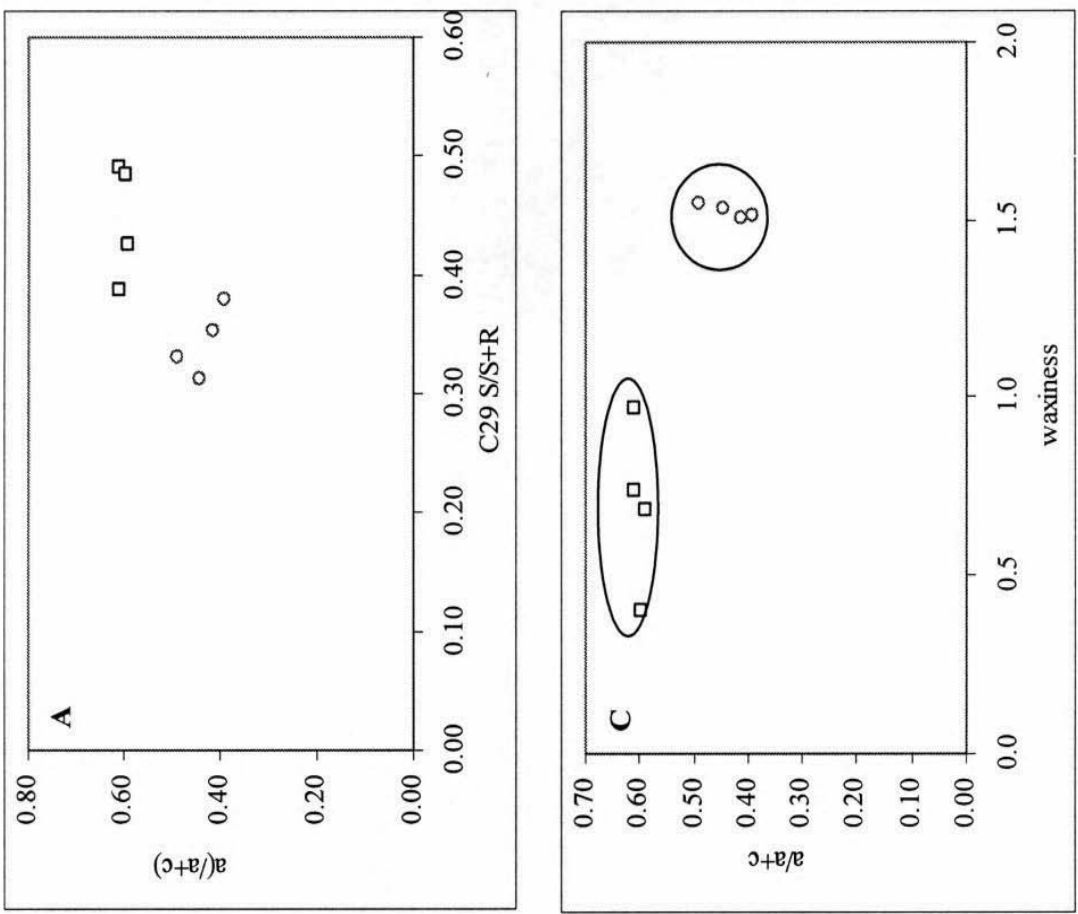

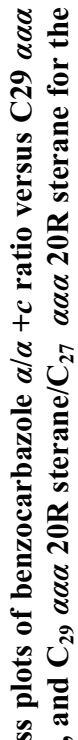

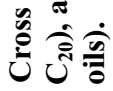

$\stackrel{0}{0}$

递 
Gharadig and Shushan oil samples, respectively. Generally, crude oil samples from the Abu Gharadig Basin have relatively high $a / a+c$ values (0.59 to 0.61), together with low $\mathrm{Pr} / \mathrm{Ph}$, low $\mathrm{C}_{29} / \mathrm{C}_{27}$ sterane and low waxiness values. On the other hand, crude oil samples from the Shushan Basin have relatively low $a /(a+c)$ values ranging from 0.39 to 0.59 , together with relatively high values of $\mathrm{Pr} / \mathrm{Ph}, \mathrm{C}_{29} / \mathrm{C}_{27}$ sterane and waxiness. The relation observed between $a /(a+c)$ parameter and $\mathrm{Pr} / \mathrm{Ph}$ in this study contradict the case reported by Bakr and Wilkes (2002) for oil from the Gulf of Suez, Egypt. It is likely that depositional environments and source retention effects have the dominant influence on the benzocarbazole distributions in the crude oil under investigation.

\section{Occurrence of Xanthones in the Western Desert Oil Fields}

Xanthones consist of a tricyclic aromatic structure including an ether and a keto function within the ring system. Xanthone and its alkylated homologues were identified in the Shushan oil samples and source rocks collected from the Jurassic Khatatba Formation. On the other hand, xanthones were absent from the Abu Gharadig oil, and occurred in very low amounts in WD-33 oil sample.

An extracted ion chromatogram displaying the distribution of xanthones in a representative Shushan oil sample is shown in Fig. 11. The concentrations in $\mu \mathrm{g} / \mathrm{g}$ oil of xanthone, the sum of methylxanthones and the sum of the $\mathrm{C}_{2}$ xanthones are illustrated in Fig. 12. All Shushan oils are enriched in xanthones. These oil samples contain all the three compound groups at concentrations ranging from 1.54 to $2.31,2.30$ to 7.41 , and 4.57 to $8.02 \mu \mathrm{g} / \mathrm{g}$ oil, for xanthone, $\mathrm{C}_{1^{-}}$, and $\mathrm{C}_{2}$-xanthones, respectively. In Abu Gharadig oils, only WD-33 sample contains 0.38, 2.67 and $0.50 \mu \mathrm{g} / \mathrm{g}$ oil of xanthone, $\mathrm{C}_{1^{-}}$, and $\mathrm{C}_{2}$-xanthones, respectively. A noteworthy feature in $\mathrm{Abu}$ Gharadig oils is that oil sample WD-33 contains higher waxy $\sum\left(n-\mathrm{C}_{21}-n-\mathrm{C}_{31}\right) / \sum\left(n-\mathrm{C}_{15}-n-\mathrm{C}_{20}\right)$ ratios than other oils of this family, reflecting relatively higher concentrations of land plant input in sample WD-33 than the remaining Abu Gharadig oil samples (Table 1).

The relative abundance of xanthone, the sum of the methylxanthones and the sum of the $\mathrm{C}_{2}$-Xanthones in the studied oil samples together with representative source rock samples from the Jurassic Khatatba Formation is shown in the ternary plot of Fig. 13. From this figure, the data show 


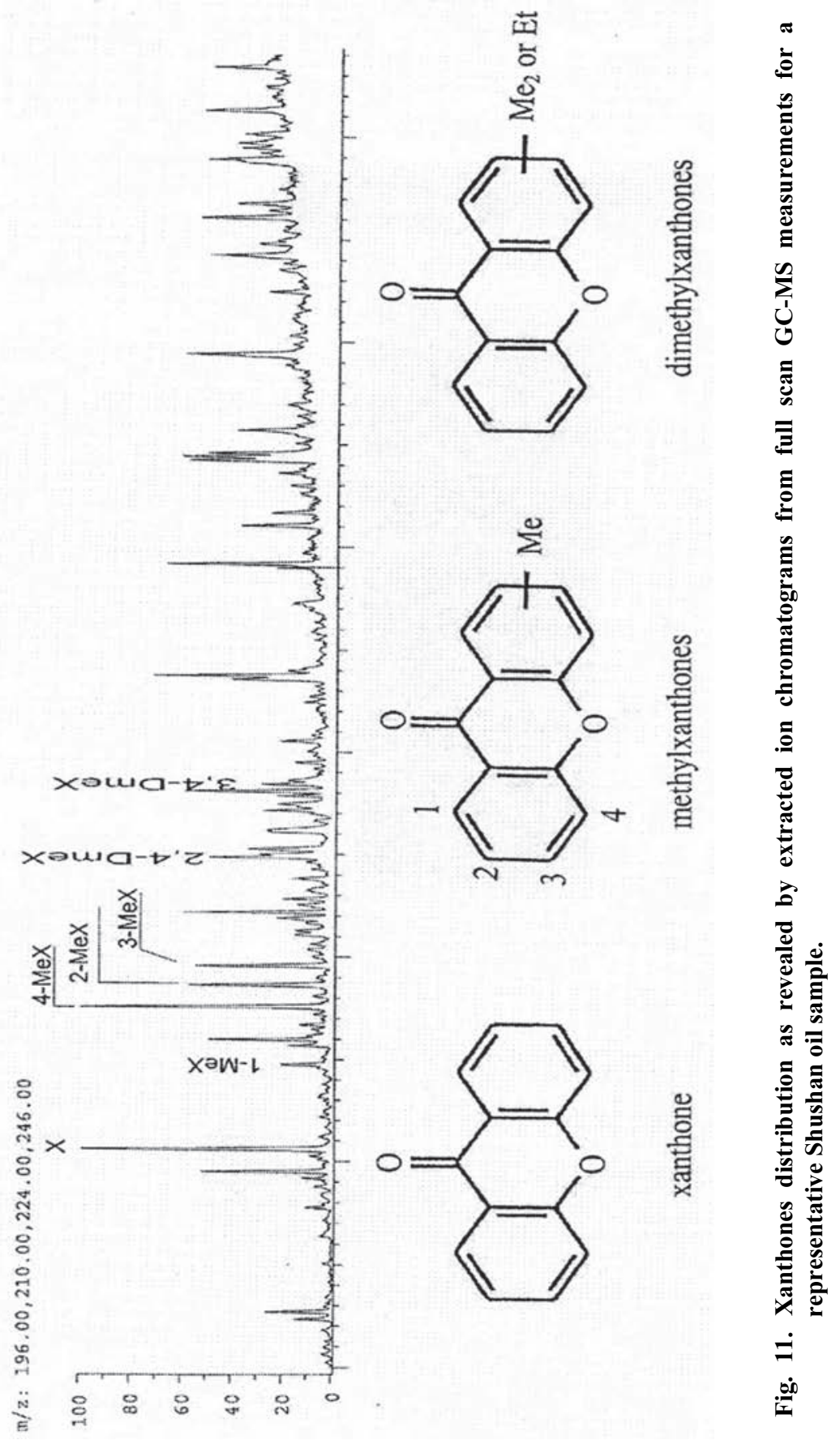



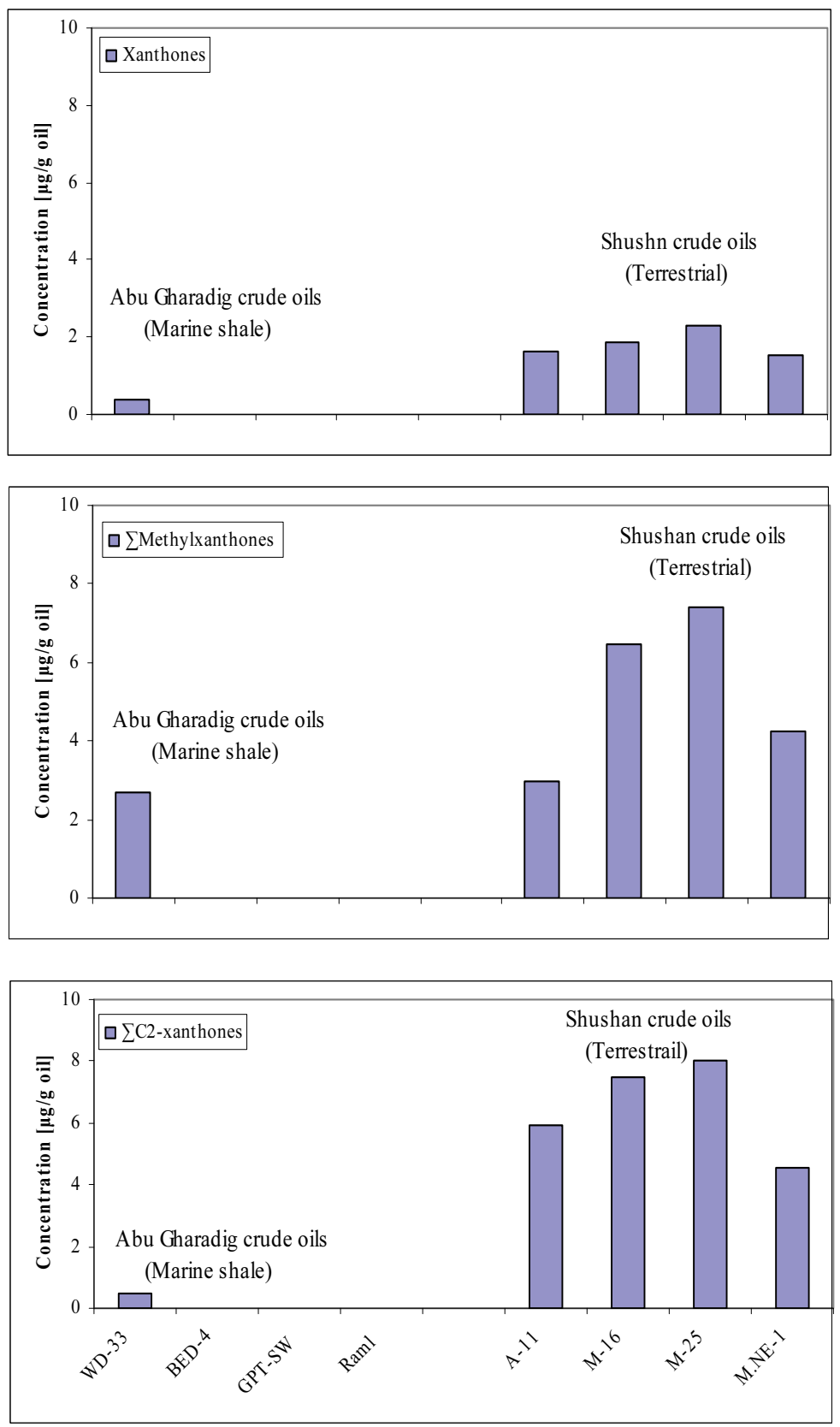

Fig. 12. Concentrations of xanthones in crude oil samples from the Abu Gharadig and Shushan basins. 
that the Khatatba source rocks contain higher proportion of xanthones than do the Shushan oils. Biomarker signatures of the Khatatba Formation extracts and Shushan oils indicate a significant contribution of terrestrial organic matter (Bakr, in press). The xanthones distributions for Shushan oils and Khatatba source rocks plot in a small area in Fig. 13, suggesting a genetic relationship between these samples. These observations clearly indicate that the most probable source of the Shushan oils is the Jurassic Khatatba rocks.

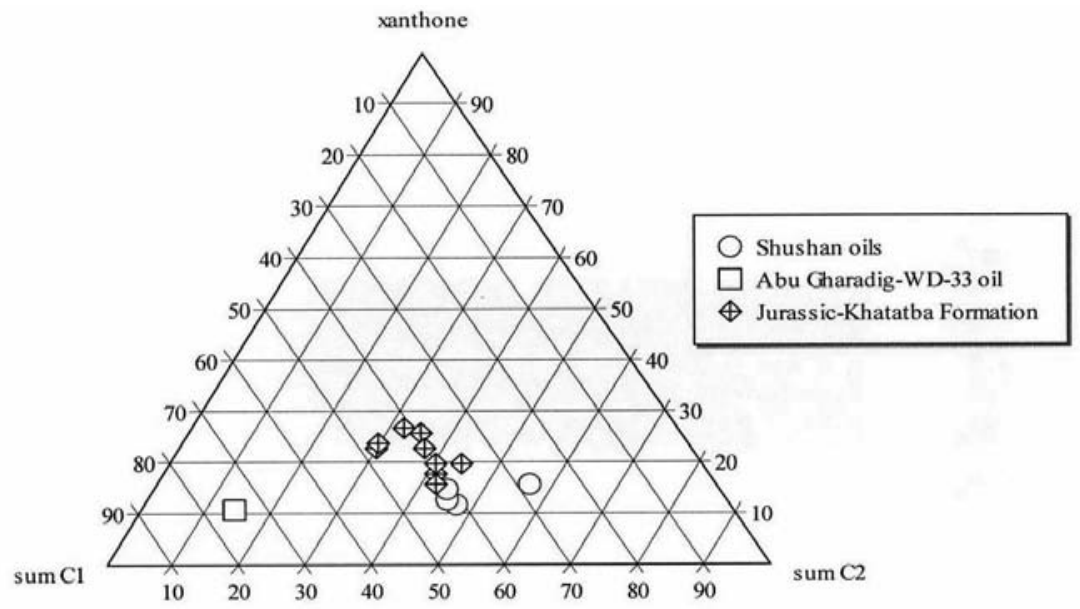

Fig. 13. Ternary diagram showing the $C_{0^{-}}, C_{1}$ and $C_{2}$-xanthones distribution in crude oil and source rock samples from the western desert of Egypt (sum $\mathrm{Cl}=\operatorname{sum} \mathrm{Cl}=$ xanthones; sum $\mathrm{C} 2=\operatorname{sum} \mathrm{C} 2=$ xanthones).

Xanthones were not detected in the Gulf of Suez petroleum system that includes both marine carbonate and clastic source rocks. Also, oils sourced from marine shale in Abu Gharadig Basin lack xanthones (except sample WD-33).

The reason behind that is most likely due to the lack of potential terrestrial plants precursors in the clastic and carbonate source rocks of these marine Egyptian petroleum systems. As far as the studied Egyptian samples are concerned, xanthones are abundant only in source extracts and crude oils that have terrestrial organic matter input. Hence, xanthones signatures show great promise as terrestrial source markers in a given petroleum system. The results of this study are preliminary; however, detailed data will be published elsewhere. 


\section{Conclusion}

The concentrations and molecular distributions of carbazole, methylcarbazoles, dimethylcarbazoles and benzocarbazoles in the Abu Gharadig and Shushan oil samples are largely controlled by source facies and depositional environments rather than reflecting maturation processes. The relative distribution of 2-, 3- and 4-methylcarbazole reveals a strong influence of the source rock. Generally, Abu Gharadig oils show a higher abundance of 1-methylcarbazole and 3+2methylcarbazoles than Shushan oils. Whereas, significantly high relative amounts of 4-methylcarbazole were found for the Shushan oil samples.

Dimethylcarbazoles are abundant in all the studied oil samples. The most significant differences between the oils of the two basins seem to be the relative amounts of 1,3-dimethylcarbazole and 1,8-dimethylcarbazole rather than the 2,7-dimethylcarbazole.

It may be concluded that the methylcarbazoles and benzocarbazole $a /(a+c)$ ratios are considered to be powerful markers for the discrimination of Abu Gharadig oils from the Shushan oils with respect to geographical origin and variations of facies and depositional environment. However, the exact controls for differences need further study.

Xanthones and its alkylated homologues were not recorded in oil samples from marine carbonate or clastic source. Xanthones are abundant in source extracts and crude oils that have terrestrial organic matter input. Based on the data of the current study, xanthones signatures show great promise as terrestrial source markers in a given petroleum system.

\section{Acknowledgments}

I would like to thank Heinz Wilkes and Brian Horsfield of the Organic Geochemistry Section at GeoForschungs Zentrum Potsdam for their invaluable support. The author is grateful to DAAD for funding a stay as a guest scientist at the Jülich Research Centre. The technical assistance of U. Disko, W. Laumer and H. Willsch is greatly acknowledged. The following oil companies generously provided oil samples: Gupco, Agiba, Bapetco, and GPC. 


\section{References}

Alexander, R., Bastow, T.P., Fisher, S.J. and Kagi, R.I. (1995) Geosynthesis of organic compounds II. Methylation of phenanthrene and alkylphenanthrenes, Geochimica et Cosmochimica Acta, 59: 4259-4266.

Bakr, M.M.Y. (2009) Molecular Organic Geochemistry of Crude Oil from Shushan and Abu Gharadig Basins, Western Desert, Egypt, Journal of King Abdulaziz University: Earth Sciences, 20(2) (this issue).

Bakr, M.M.Y. and Wilkes, H. (2002) The influence of facies and depositional environment on the occurrence and distribution of carbazoles and benzocarbazoles in crude oil: A case study from the Gulf of Suez, Egypt, Organic Geochemistry, 33: 561-580.

Ball, J.S., Whisman, M.L. and Wenger, W.J. (1951) Nitrogen content of crude petroleums, Industrial and Engineering Chemistry, 43: 2577-2581.

Baxby, M., Patience, R.L. and Bartle, K.D. (1994) The origin and diagenesis of sedimentary organic nitrogen, Journal of Petroleum Geology, 17: 211-230.

Berti, G. and Bottari, F. (1968) Constituents of ferns. In: Reinhold, L. and Liwschitz, Y. (ed.), Progress in Phytochemistry 1, John Wiley \& Sons, New York, 589-685.

Bowler, B.F.J., Larter, S.R., Clegg, H., Wilkes, H., Horsfield, B. and Li, M. (1997) Dimethylcarbazoles in crude oil: Comment on "Liquid chromatographic separation schemes for pyrrole and pyridine nitrogen aromatic heterocyclic fractions from crude oil suitable for rapid characterization of geochemical samples", Analytical Chemistry, 69: 3128-3129.

Chexal, K.K., Holker, J.S.E., Simpon, T.J. and Young, K. (1975) The biosynthesis of fungal metabolites, part V, Journal of the Chemical Society, 1: 543-548.

Clegg, H., Wilkes, H. and Horsfield, B. (1997) Carbazole distributions in carbonate and clastic source rocks, Geochimica et Cosmochimica Acta, 61: 5335-5345.

Clegg, H., Horsfield, B., Wilkes, H., Sinninghe Damsté, J.S. and Koopmans, M.P. (1998a) Effect of artificial maturation on carbazole distributions, as revealed by the hydrous pyrolysis of an organic-sulphur-rich source rock (Ghareb Formation, Jordan), Organic Geochemistry, 29: 1953-1960.

Clegg, H., Wilkes, H., Oldenburg, T., Santamaría-Orozco, D. and Horsfield, B. (1998b) Influence of maturity on carbazole and benzocarbazole distributions in crude oil and source rocks from the Sonda de Campeche, Gulf of Mexico, Organic Geochemistry, 29: 183-194.

Culberson, C.F. (1969) Chemical and Botanical Guide to Lichen Products, University of North Carolina Press, Chapel Hill.

Devon, T.K. and Scott, A.I. (1975) Handbook of Naturally Occurring Compounds, Academic Press, New York.

Dorbon, M., Garrigues, P., Igniatiadis, I., Edward, M., Arpino, P. and Guichon, G. (1984) Distribution of carbazole derivatives in petroleum, Organic Geochemistry, 7: 111-120.

EGPC (1992) Western Desert oil and gas fields-a comprehensive overview, The Egyptian General Petroleum Corporation, Cairo, Egypt, 431 p.

Harrison, E., Telnæs, N., Wilhelms, A., Horsfield, B., van Duin, A., Bennet, B. and Larter, S.R. (1997) Maturity controls on carbazole distribution in coals and source rocks. In: Organic Geochemistry, Poster Sessions from the $18^{\text {th }}$ International Meeting on Organic Geochemistry, 22-26 September 1997, Maastricht, The Netherlands, 235-236.

Horsfield, B., Clegg, H., Wilkes, H. and Santamaría-Orozco, D. (1998) Effect of maturity on carbazole distributions in petroleum systems: new insights from the Sonda de Campeche (Mexico) and Hils Syncline (Germany), Naturwissenschaften, 85: 233-237.

Iopppolo-Armanios, M., Alexander, R. and Kagi, R.I. (1994) Geosynthesis of organic compounds: I. Alkylphenols, Geochimica et Cosmochimica Acta, 59: 3017-3027. 
Larter, S.R., Bowler, B.F.J., Li, M., Chen, M., Brincat, D., Bennett, B., Noke, K., Donohoe, P., Simmons, D., Kohnen, M., Allan, J., Telnæs, N. and Horstad, I. (1996) Molecular indicators of secondary oil migration distances, Nature, 383: 593-597.

Larter, S.R., Bowler, B.F.J., Clarke, E., Wilson, C., Moffat, B., Bennett, B., Yardley, G. and Carruthers, D. (2000) An experimental investigation of geochromatography during secondary migration of petroleum performed under subsurface conditions with a real rock, Geochemical Transactions, p. 9.

Li, M., Larter, S.R., Frolov, Y.B. and Bjorøy, M. (1994) Adsorptive interactions between nitrogen compounds and organic and/or mineral phases in subsurface rocks. Models for compositional fractionation of pyrrolic nitrogen compounds in petroleum during petroleum migration, Journal of High Resolution Chromatography, 17: 230-236.

Li, M., Larter, S.R., Stoddart, D. and Bjorøy, M. (1995) Fractionation of pyrrolic nitrogen compounds in petroleum during migration: derivation of migration-related geochemical parameters. In: Cubitt, J.M. and England, W.A. (ed.), The Geochemistry of Reservoirs, Geological Society, London. pp: 103-123.

Li, M., Yao, H., Stasiuk, L.D., Fowler, M.G. and Larter, S.R. (1997) Effect of maturity and petroleum expulsion on pyrrolic nitrogen compound yields and distributions in Duvernay Formation petroleum source rocks in central Alberta, Canada, Organic Geochemistry, 26: 731-744.

Li, M., Yao, H., Fowler, M.G. and Stasiuk, L.D. (1998) Geochemical constraints on models for secondary petroleum migration along the Upper Devonian Rimbey-Meadowbrook reef trend in central Alberta, Canada. Organic Geochemistry, 29: 163-182.

Li, M., Fowler, M.G., Obermajer, M., Stasiuk, L.D. and Snowdon, L.R. (1999) Geochemical characterisation of Middle Devonian oil in NW Alberta, Canada: possible source and maturity effect on pyrrolic nitrogen compounds, Organic Geochemistry, 30: 1039-1057.

Oldenburg, T.B.P., Wilkes, H., Horsfield, B., van Duin, A.C.T., Stoddart, D. and Wilhelms, A. (2002) Xanthones - novel aromatic oxygen-containing compounds in crude oil, Organic Geochemistry, 33: 595-609.

Peres, V. and Nagem, T.J. (1997) Trioxygenated naturally occurring xanthones, Phytochemistry, 44: 191-214.

Peres, V., Nagem, T.J. and de Oliveira, F.F. (2000) Tetraoxygentated naturally occurring xanthones, Phytochemistry, 55: 683-710.

Petroconsultant - International Energy Services (1997) Egypt-Western Desert \& Nile Delta.

Radke, M., Willsch, H. and Welte, D.H. (1980) Preparative hydrocarbon group type determination by automated medium pressure liquid chromatography, Analytical Chemistry, 52: 406-411.

Radke, M., Willsch, H. and Leythaeuser, D. (1982) Aromatic components of coal: relation of distribution pattern to rank, Geochimica et Cosmochimica Acta, 46: 1831-1848.

Richter, F.P., Ceaser, P.D., Meisel, S.L. and Offenhauer, R.D. (1952) Distribution of nitrogen in petroleum according to basicity, Industrial and Engineering Chemistry, 44: 2601-2605.

Silliman, J.E., Li, M., Yao, H. and Hwang, R. (2002) Molecular distributions and geological implications of pyrrolic nitrogen compounds in the Permian Phosphoria Formation derived oil of Wyoming, Organic Geochemistry, 33: 527-544.

Snyder, L.R., Buell, B.E. and Howard, H.E. (1968) Nitrogen and oxygen compound types in petroleum, Analytical Chemistry, 40: 1303-1317.

Terken, J.M.J. and Frewin, N.L. (2000) The Dhahaban petroleum system of Oman, The American Association of Petroleum Geologists Bulletin, 84: 523-544.

Tissot, B.P. and Welte, D.H. (1984) Petroleum Formation and Occurrence, Springer, Berlin, p. 699.

Tomasek, P.H. and Crawford, R.L. (1986) Initial reactions of xanthone biodegradation by an Arthrobacter sp, Journal of Bacteriology, 167: 818-827. 
Wilhelms, A., Patience, R.L., Larter, S.R. and Jorgensen, S. (1992) Nitrogen functionality distributions in asphaltenes isolated from several oil from different source rock types, Geochimica et Cosmochimica Acta, 56: 3745-3750.

Wilhelms, A., Telnaes, N., Larter, S.R., Steen, A., Bowler, B. and Ronningsland, T.M. (1997) Application of migration indicators (benzocarbazoles) in unraveling of the filling history of the Oseberg field, North Sea. In: Abstracts of the $18^{\text {th }}$ International Meeting on Organic Geochemistry, Maastricht, 22-26 September 1997, pp: 745-746.

Wu, Q.L., Wang, S.P., Du, L.J., Yang, J.S. and Xiao, P.G. (1998) Xanthones from Hypericum Japonicum and H. Henryi, Phytochemistry, 49: 1395-1402.

Zhu, Y., Xiang, T., Mei, B., Fu, J. and Sheng, G. (1997) Geochemical significance of pyrrolic nitrogen compounds in various kinds of oil from the Tarim Basin, China. In: Abstracts of the 18th International Meeting on Organic Geochemistry, Maastricht, 22-26 September 1997, pp: 383-384. 


\section{وجود مركبات الكربازول و الز انسون ودلالتها الجيوكيميائية في زيت النفط بالصحر اء الغربية بمصر}

\section{محمد محمد يوسف بكر}

قسم جيولوجيا البترول و الترسبات - كلية علوم الأرض بوسن جامعة الملك عبدالعزيز - جدة - المدلكة العربية السعودية

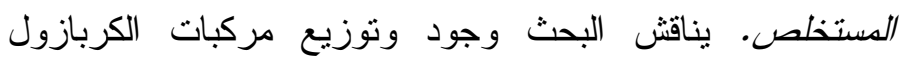

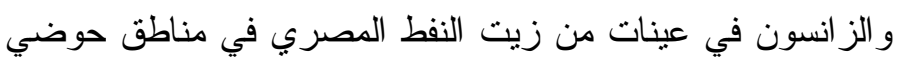
ترسيب أبو الغر اديق وشوشان بالصحر اء الغربية. توصف مرئ مركبات

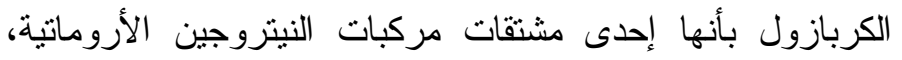
بينما تعتبر مركبات الزانسون إحدى مشتقات مركبات الأوكسجين

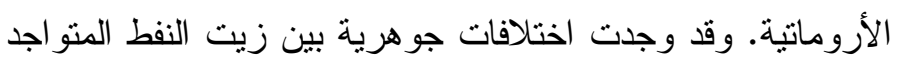

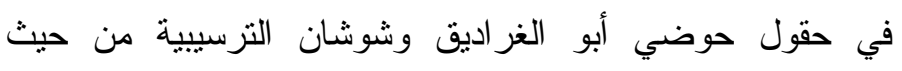

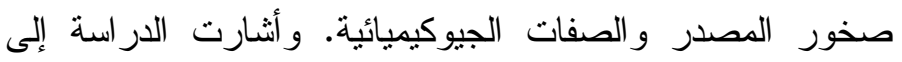

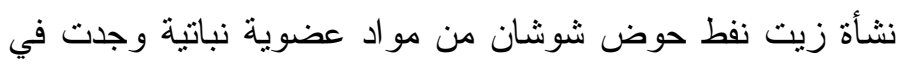

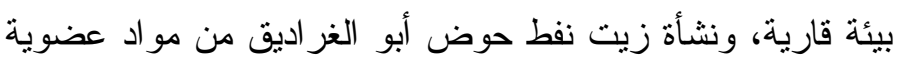
تكونت فى بيئة بحرية غنية بسحنات الطفلة.

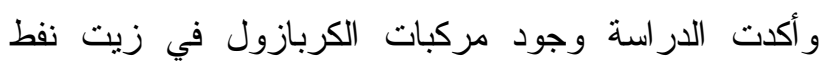

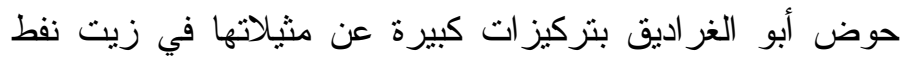

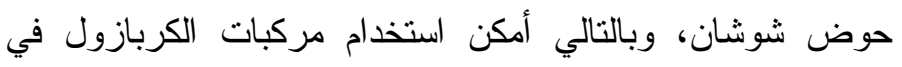

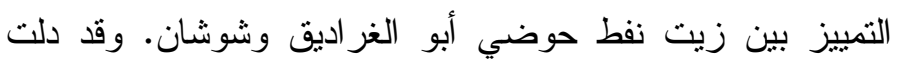

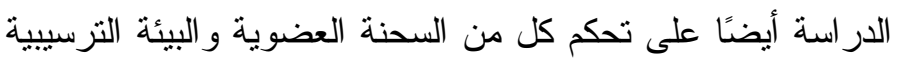

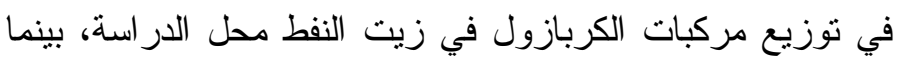

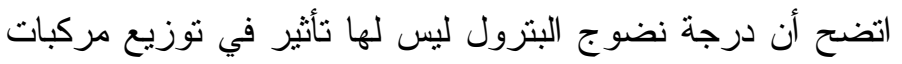


أما بالنسبة لمركبات الزانسون وهي مركبات ذات صفات

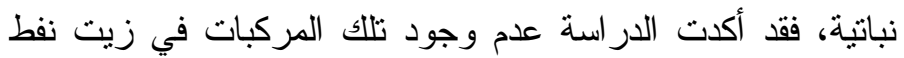

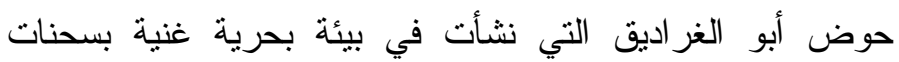

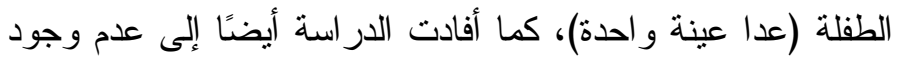
مركبات الزانسون في زيوت نفط خليج السويس التي نكونت في بيئة بحرية غنية بسحنات كربونات أو سحنات طفلة، بينما أثنارت

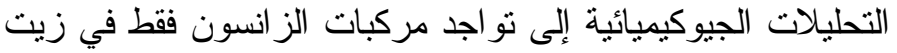

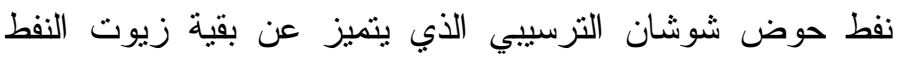

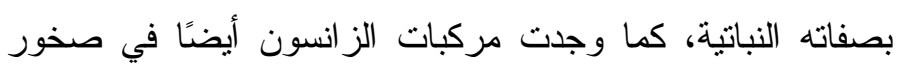
مصدر منكون الخطاطبة ذات الصفات النباتية. 